2015

\title{
Submarine Groundwater Discharge of Rare Earth Elements to a Tidally-Mixed Estuary in Southern Rhode Island
}

\author{
Darren A. Chevis \\ Karen H. Johannesson \\ David J. Burdige \\ Old Dominion University, dburdige@odu.edu \\ Jianwu Tang \\ S. Bradley Moran
}

See next page for additional authors

Follow this and additional works at: https://digitalcommons.odu.edu/oeas_fac_pubs

\section{Repository Citation}

Chevis, Darren A.; Johannesson, Karen H.; Burdige, David J.; Tang, Jianwu; Moran, S. Bradley; and Kelly, Roger P., "Submarine Groundwater Discharge of Rare Earth Elements to a Tidally-Mixed Estuary in Southern Rhode Island" (2015). OEAS Faculty Publications. 146.

https://digitalcommons.odu.edu/oeas_fac_pubs/146

\section{Original Publication Citation}

Chevis, D. A., Johannesson, K. H., Burdige, D. J., Tang, J., Bradley Moran, S., \& Kelly, R. P. (2015). Submarine groundwater discharge of rare earth elements to a tidally-mixed estuary in Southern Rhode Island. Chemical Geology, 397, 128-142. doi: 10.1016/

j.chemgeo.2015.01.013 
Authors

Darren A. Chevis, Karen H. Johannesson, David J. Burdige, Jianwu Tang, S. Bradley Moran, and Roger P. Kelly 


\title{
Submarine groundwater discharge of rare earth elements to a tidally-mixed estuary in Southern Rhode Island
}

\author{
Darren A. Chevis ${ }^{\mathrm{a}, *}$, Karen H. Johannesson ${ }^{\mathrm{a}}$, David J. Burdige ${ }^{\mathrm{b}}$, Jianwu Tang ${ }^{\mathrm{a}}$, S. Bradley Moran ${ }^{\mathrm{c}}$, Roger P. Kelly ${ }^{\mathrm{c}}$ \\ a Department of Earth and Environmental Sciences, Tulane University, New Orleans, LA 70118, United States \\ ${ }^{\mathrm{b}}$ Department of Ocean, Earth, and Atmospheric Sciences, Old Dominion University, Norfolk, VA 23529, United States \\ c Graduate School of Oceanography, University of Rhode Island, Narragansett, RI 02882, United States
}

\section{A R T I C L E I N F O}

\section{Article history:}

Received 10 October 2014

Received in revised form 11 January 2015

Accepted 18 January 2015

Available online 31 January 2015

Editor: Carla M Koretsky

\section{Keywords:}

Rare earth elements

Submarine groundwater discharge

Nd paradox

\begin{abstract}
A B S T R A C T
Rare earth element (REE) concentrations were analyzed in surface water and submarine groundwater within the Pettaquamscutt Estuary, located on the western edge of Narragansett Bay in Rhode Island. These water samples were collected along the salinity gradient of the estuary. Rare earth element concentrations in the majority of the groundwater samples are substantially higher than their concentrations in the surface waters. In particular, $\mathrm{Nd}$ concentrations in groundwater range from $0.43 \mathrm{nmol} \mathrm{kg}{ }^{-1}$ up to $198 \mathrm{nmol} \mathrm{kg}{ }^{-1}$ (mean \pm SD $=42.1 \pm$ $87.2 \mathrm{nmol} \mathrm{kg}{ }^{-1}$ ), whereas $\mathrm{Nd}$ concentrations range between $259 \mathrm{pmol} \mathrm{kg}{ }^{-1}$ and $649 \mathrm{pmol} \mathrm{kg}^{-1}\left(\mathrm{mean}^{\mathrm{n}} \pm\right.$ $\mathrm{SD}=421 \pm 149 \mathrm{pmol} \mathrm{kg}^{-1}$ ) in surface waters from the estuary, which is, on average, 100 fold lower than $\mathrm{Nd}$ in the groundwaters. Groundwater samples all exhibit broadly similar middle REE (MREE) enriched shalenormalized REE patterns, despite the wide variation in $\mathrm{pH}$ of these natural waters $(4.87 \leq \mathrm{pH} \leq 8.13)$. The similarity of the shale-normalized REE patterns across the observed $\mathrm{pH}$ range suggests that weathering of accessory minerals, such as apatite, and/or precipitation of LREE enriched secondary phosphate minerals controls groundwater REE concentrations and fractionation patterns. More specifically, geochemical mixing models suggest that the REE fractionation patterns of the surface waters may be controlled by REE phosphate mineral precipitation during the mixing of groundwater and stream water with incoming water from the Rhode Island Sound. The estimated SGD (Submarine Groundwater Discharge) of Nd to the Pettaquamscutt Estuary is $26 \pm 11 \mathrm{mmol} \mathrm{Nd} \mathrm{day}^{-1}$, which is in reasonable agreement with the Nd flux of the primary surface water source to the estuary, the Gilbert Stuart Stream (i.e., $36 \mathrm{mmol}_{\text {day }}{ }^{-1}$ ), and of the same order of magnitude for a site in Florida.
\end{abstract}

(c) 2015 Elsevier B.V. All rights reserved.

\section{Introduction}

Submarine groundwater discharge (SGD) is most commonly defined as water that flows from the seafloor to the overlying marine water column on the continental margin, without regard to the origin or composition of the fluid (Burnett et al., 2003). Thus, SGD can be driven by several mechanisms, including terrestrial hydraulic gradients, tidal and wave action, temperature and density differences, and bioirrigation (Li et al., 1999; Kelly and Moran, 2002; Michael et al., 2005; Moore and Wilson, 2005; Martin et al., 2007; Smith et al., 2008a,b). Through the use of geochemical tracers such as ${ }^{222} \mathrm{Rn}$ and radium isotopes, a number of studies have shown that SGD can contribute a substantial amount of water to the coastal ocean, which can be of similar magnitude as river input (Cable et al., 1996; Moore, 1996, 2010; Moore et al., 2008). Specifically, Moore (2010) reported that the annual average SGD flux to the South Atlantic Bight on the southeastern coast of the U.S.A. is three times greater than riverine supply in this region. Furthermore, SGD has also been reported to be an important source of nutrients and trace elements to the coastal

\footnotetext{
* Corresponding author.

E-mail address: dchevis@tulane.edu (D.A. Chevis).
}

ocean (Kelly and Moran, 2002; Duncan and Shaw, 2003; Charette and Sholkovitz, 2006; Johannesson et al., 2011).

Recently, Johannesson and Burdige (2007) examined the contribution of SGD to the flux of rare earth elements (REEs) to the coastal ocean and suggested that SGD may be a source of the missing Nd required to resolve the "Nd Paradox". Resolving the "Nd Paradox", which refers to the apparent decoupling of the Nd concentration profiles and present-day Nd isotopic measurements, $\varepsilon_{\mathrm{Nd}}(0)$, in the ocean (Bertram and Elderfield, 1993; Jeandel et al., 1995; Goldstein and Hemming, 2003), is important because Nd isotopes are widely used to investigate past changes in ocean circulation over glacialinterglacial periods (Frank, 2002; Goldstein and Hemming, 2003; Via and Thomas, 2006; Muinos et al., 2008). Johannesson and Burdige (2007) computed a mean $\mathrm{Nd}$ concentration and $\varepsilon_{\mathrm{Nd}}(0)$ value by employing data from previous studies of terrestrial groundwater, together with an estimate of the terrestrial SGD volumetric flow rate, to compute an SGD Nd flux. The computed SGD Nd flux by Johannesson and Burdige (2007) is similar to the "missing Nd" flux that Tachikawa et al. (2003) and Arsouze et al. (2009) proposed was needed to balance the ocean Nd budget. Despite the relatively good agreement between the "missing Nd flux" and the estimated terrestrial SGD Nd flux, 
Johannesson and Burdige (2007) did not explicitly account for the recirculated, saline SGD component (marine SGD) of total SGD, which can be important for some trace elements such as Fe (Taniguchi et al., 2002; Roy et al., 2010, 2011), nor did they measure Nd in actual SGD.

Recent investigations of REEs that account for the terrestrial and marine components of SGD indicate that SGD is an important source of REEs to the overlying surface waters (e.g., Duncan and Shaw, 2003; Johannesson et al., 2011; Kim and Kim, 2011, 2014; Chevis et al., in review). Duncan and Shaw (2003) reported, for example, that SGD exiting the North Inlet surficial aquifer, South Carolina, exhibits an increase in REE concentration with salinity. Lower salinity groundwaters of the North Inlet surficial aquifer display shale-normalized HREEenriched patterns that differ from the primarily LREE-enriched high salinity groundwaters. Submarine groundwater discharge of the REEs to the Indian River Lagoon along Florida's Atlantic coast appears to originate from two distinct sources: a HREE-enriched flux derived from the advection of terrestrial groundwater; and a LREE-enriched flux derived from bioirrigation of marine porewater (Johannesson et al., 2011; Chevis et al., in review). The cycling of REEs in the Indian River Lagoon is closely linked to the Fe cycle in contrast to the North Inlet where REEs are instead released due to degradation of REE-rich, relic terrestrial organic carbon (Duncan and Shaw, 2003). More recently, Kim and $\operatorname{Kim}(2011,2014)$ showed that SGD was a major source of REEs to local coastal waters off Jeju Island, Korea. All of these studies point to the need for further investigation of SGD REE fluxes to ultimately compute a global SGD flux of these important trace elements to the ocean.

In this study, we present REE data in surface water and groundwater of the Pettaquamscutt Estuary, Rhode Island, USA, and evaluate the cycling of REEs in the underlying subterranean estuary. Local aquifers consist of fractured Proterozoic and Paleozoic crystalline bedrock and associated overlying glacial deposits (Hermes et al., 1994), and thus differ lithologically from other sites investigated to date (i.e., North Inlet, South Carolina; Indian River Lagoon, Florida; Jeju Island, South Korea). Hence, the subterranean estuary associated with the Pettaquamscutt Estuary represents a system underlain by old, felsic igneous and related metamorphic rocks and associated glacial sediments, where the REE behavior and SGD fluxes can be compared with our previous work in the Holocene, mixed carbonate-siliciclastic system (i.e., Anastasia Formation) of the Indian River Lagoon, Florida, USA (Johannesson et al., 2011; Chevis et al., in review).

\section{Field site}

The Pettaquamscutt Estuary is located on the western edge of Narragansett Bay in the State of Rhode Island (Fig. 1). The average depth of the estuary is $2 \mathrm{~m}$; however, there are two deep, stratified anoxic basins, located north of Station 3 (Sta. 3; Fig. 1), with average depths of $\sim 20 \mathrm{~m}$ (Kelly and Moran, 2002, and references within). The majority of the associated drainage basin consists of glacial outwash and till deposited on top of Pennsylvanian metasedimentary rocks of the Rhode Island Formation (Hermes et al., 1994; Boothroyd and August, 2008; Nowicki and Gold, 2008). Late Proterozoic ( 630$600 \mathrm{Ma}$ ) felsic intrusive rocks of the Esmond Igneous Suite characterize the northwestern and western portions of the drainage basin (Hermes and Zartman, 1985; Hermes et al., 1994; Kelly and Moran, 2002). The southern-most portion of the Pettaquamscutt Estuary is underlain by the Permian Narragansett Pier Granite, which intrudes the Rhode Island Formation (Zartman and Hermes, 1987).

The Gilbert Stuart Stream is the predominant surface source of freshwater to the Pettaquamscutt Estuary, and is estimated to discharge $\sim 1 \times 10^{8} \mathrm{~L} \mathrm{day}^{-1}$ of water to the estuary (Siffling, 1997). Estuarine circulation within the Pettaquamscutt Estuary is tidally controlled and the tidal prism volume is estimated at $1 \times 10^{9} \mathrm{~L}$ (Siffling, 1997; Kelly and Moran, 2002). Early estimates of groundwater discharge to the Pettaquamscutt, based on tidal exchange (Siffling, 1997) and hydrologic modeling (De Meneses, 1990) suggest that groundwater could account for $50 \%-60 \%$ of the freshwater input to the estuary. Kelly and Moran (2002) employed ${ }^{226} \mathrm{Ra}$ and ${ }^{228} \mathrm{Ra}$ to estimate the magnitude of the SGD flux to the estuary and showed that it varies seasonally with the highest input of SGD occurring in the summer months $\left(1.2 \times 10^{7}-3.78 \times 10^{7} \mathrm{~L} \mathrm{day}^{-1}\right)$ and the lowest SGD input occurring during the winter $\left(0.4 \times 10^{7}-1.3 \times 10^{7} \mathrm{~L} \mathrm{day}^{-1}\right)$. Using water residence times in the Pettaquamscutt Estuary ranging between 7 and 20 days (based on Ra isotope analysis and tidal prism calculations), Kelly and Moran (2002) estimated that the average yearly volume of SGD entering the estuary is computed to range from $3.2 \times 10^{9}$ to $9.4 \times 10^{9} \mathrm{~L}$. These SGD estimates to the estuary are broadly similar to an independent estimate of the aquifer recharge balance in the drainage basin $\left(10 \times 10^{9} \mathrm{~L}\right.$; Kelly and Moran, 2002) suggesting that the system is in balance.

\section{Methods}

\subsection{Sample collection}

Groundwater and surface water samples were collected in October 2010 from the same locations previously sampled by Kelly and Moran (2002) (Fig. 1). Groundwater samples were collected from depths of less than $2 \mathrm{~m}$ below the surface using a drive-point piezometer. A peristaltic pump was employed to extract groundwater through previously cleaned, acid-washed Teflon $®$ tubing attached to the tip of the drivepoint. For groundwaters and surface waters, $1 \mathrm{~L}$ of water was filtered through $0.45 \mu \mathrm{m}$ (pore-size) in-line filter cartridges (Gelman Science, polyether sulfone membrane) attached to the output end of the Teflon ${ }^{\circledR}$ tube, and collected into acid-cleaned HDPE bottles in the field after first rinsing the bottle three times with the filtered water to condition the bottle (Johannesson et al., 2004). All water samples for REE analysis were sealed in two Ziplock®-style polyethylene bags for transport back to the clean laboratory of the Graduate School of Oceanography (GRO) of the University of Rhode Island acidified to $\mathrm{pH}<2$ with ultrapure $\mathrm{HNO}_{3}$ (Seastar Chemicals, Inc., Baseline) using ultra-clean procedures (Johannesson et al., 2004) within $5 \mathrm{~h}$ of collection. Along with the REE samples, $\sim 125 \mathrm{~mL}$ of water at each sampling site was similarly collected for major cation $\left(\mathrm{Ca}^{2+}, \mathrm{Mg}^{2+}, \mathrm{Na}^{+}, \mathrm{K}^{+}\right)$and for major anion $\left(\mathrm{Cl}^{-}, \mathrm{SO}_{4}^{2-}\right)$ analysis. Major cation samples were acidified with a drop of ultra-pure $\mathrm{HNO}_{3}$ (Seastar Chemicals, Inc., Baseline), but the anion samples were not acidified. For DOC analysis, a small aliquot of each filtered sample was taken with a $50 \mathrm{~mL}$ polypropylene syringe and stored in a cooler for transport to the laboratory at the GRO of the University of Rhode Island. Once at the laboratory, $5 \mathrm{~mL}$ of each sample was placed in individual $10 \mathrm{~mL}$ glass ampules (cleaned and precombusted in a muffle furnace prior to use) and acidified with $50 \mu \mathrm{L}$ of $6 \mathrm{M} \mathrm{HCl}$. The ampules were then torched sealed and stored refrigerated until the time of analysis.

\subsection{Sample analysis}

Major solutes $\left(\mathrm{Ca}^{2+}, \mathrm{Mg}^{2+}, \mathrm{Na}^{+}, \mathrm{K}^{+}, \mathrm{Cl}^{-}, \mathrm{SO}_{4}^{2-}\right)$ were measured in pore and surface waters by ion chromatography (Dionex DX300) at The Ohio State University following the procedure of Welch et al. (1996). Alkalinity was titrated in the field on filtered water samples using a "digital" titrator (Hach, Model 16900) and either $0.8 \mathrm{M}$ or $0.08 \mathrm{M} \mathrm{H}_{2} \mathrm{SO}_{4}$. Measurements for dissolved Fe (II), total Fe, and $\Sigma \mathrm{S}(-\mathrm{II})$ $\left(=\mathrm{H}_{2} \mathrm{~S}+\mathrm{HS}^{-}+\mathrm{S}^{2-}+\ldots\right)$ in the groundwater samples were quantified in the field using a Hach $\odot 2800$ portable spectrophotometer (Haque et al., 2008; Willis and Johannesson, 2011). Dissolved Fe (II) was determined using the 1,10-Phenanthroline method, and total dissolved Fe was determined by the FerroVerr method (Eaton et al., 1995a). The method detection limits for the Fe (II) and total Fe methods are $0.36 \mu \mathrm{mol} \mathrm{kg} \mathrm{kg}^{-1}$ and $0.16 \mu \mathrm{mol} \mathrm{kg}{ }^{-1}$, respectively (Eaton et al., 1995a). Dissolved S (-II) was measured by the methylene blue method (Eaton et al., 1995b). The detection limit for the methylene blue method is $0.29 \mu \mathrm{mol} \mathrm{kg}{ }^{-1}$ of S (-II) (Cline, 1969; Eaton et al., 1995b). Dissolved 


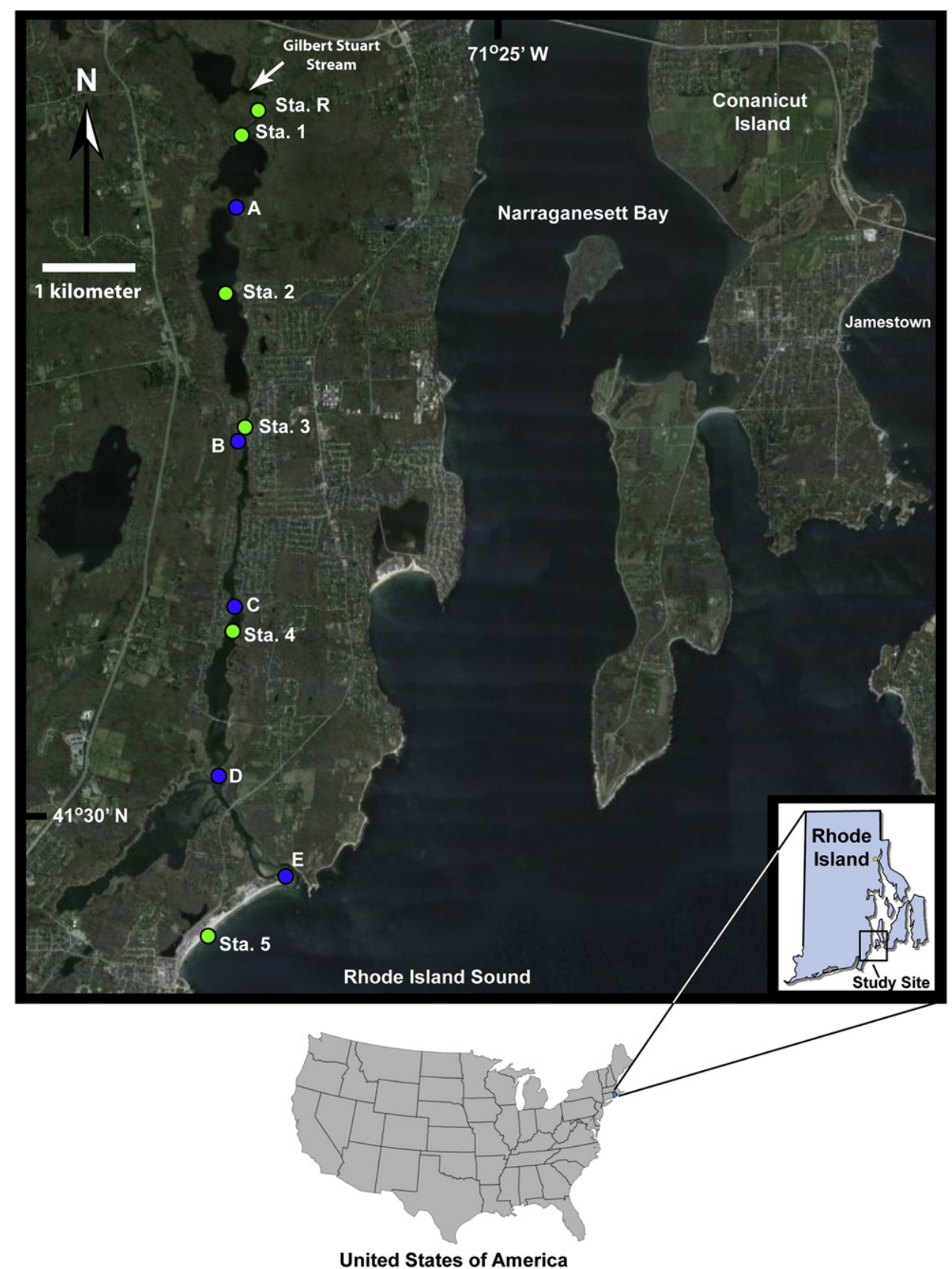

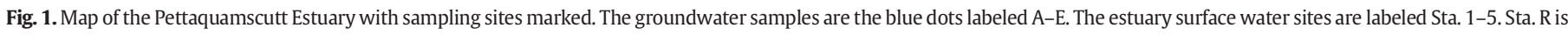
the sample of the Gilbert Stuart Stream.

organic carbon concentrations were quantified at Old Dominion University by high temperature combustion using a Shimadzu TOC-V total carbon analyzer.

For the REE analyses, approximately $60 \mathrm{~mL}$ of each sample was passed through Bio-Rad ${ }^{\circledR}$ Poly-Prep columns packed with $\sim 2 \mathrm{~mL}$ of Bio-Rad® AG $50 \mathrm{~W}$-X8 (100-200 mesh, hydrogen form) cationexchange resin to separate the REEs from the major dissolved solutes (Greaves et al., 1989; Johannesson et al., 2005, 2011). Two $3 \mathrm{~mL}$ acid rinses of $1.75 \mathrm{M}$ ultra-pure $\mathrm{HCl}$ and $2 \mathrm{M}$ ultra-pure $\mathrm{HNO}_{3}$ were performed to elute Fe and Ba, respectively, from the columns. The REEs were then eluted from each column with $10 \mathrm{~mL}$ of $8 \mathrm{M}$ ultrapure $\mathrm{HNO}_{3}$, and the eluted solutions collected in Teflon ${ }^{\circledR}$ beakers. The sample was evaporated to dryness and subsequently taken up in $10 \mathrm{~mL}$ of a $1 \% \mathrm{v} / \mathrm{v}$ ultra-pure $\mathrm{HNO}_{3}$ solution. Because of high total REE concentrations, groundwater samples B, C, and D were rerun using ferric iron coprecipitation (Wiesel et al., 1984; Welch et al.,
1990). Here, $200 \mu \mathrm{L}$ of an $\sim 1 \mathrm{M}$ ferric nitrate solution was added to $50 \mathrm{~mL}$ of sample. Approximately $3 \mathrm{~mL}$ of ultra-pure ammonium hydroxide $(30 \% \mathrm{v} / \mathrm{v})$ was added to induce the precipitation of the dissolved iron. The samples were briefly shaken and left for an hour to allow the precipitate to form. The samples were then centrifuged and the supernatant was removed. The precipitate was rinsed with Milli-Q water and then centrifuged again and the supernatant was removed. The ferric hydroxide precipitate was then dissolved in $2 \mathrm{M} \mathrm{HCl}$, and the resulting solution was then passed Bio-Rad ${ }^{\circledR}$ Poly-Prep columns packed with $\sim 2 \mathrm{~mL}$ of Bio-Rad® AG $50 \mathrm{~W}-\mathrm{X} 8$ (100-200 mesh, hydrogen form) cation-exchange resin to separate the REEs from the major dissolved solutes following the procedure described above. The only difference was that the $1.75 \mathrm{M} \mathrm{HCl}$ rinse was omitted due to the fact that the sample matrix was $2 \mathrm{M} \mathrm{HCl}$ and, therefore, should prevent the Fe in solution from binding to the cation exchange resin. 
Each water sample was spiked with ${ }^{115}$ In at $1 \mu \mathrm{g} \mathrm{kg}^{-1}$ for use as an internal standard and run for the REEs by HR-ICP-MS (Thermo Fisher Element II) at Tulane University. We monitored ${ }^{139} \mathrm{La},{ }^{140} \mathrm{Ce},{ }^{141} \mathrm{Pr}$, ${ }^{143} \mathrm{Nd},{ }^{145} \mathrm{Nd},{ }^{146} \mathrm{Nd},{ }^{147} \mathrm{Sm},{ }^{149} \mathrm{Sm},{ }^{151} \mathrm{Eu},{ }^{153} \mathrm{Eu},{ }^{155} \mathrm{Gd},{ }^{157} \mathrm{Gd},{ }^{158} \mathrm{Gd}$, ${ }^{159} \mathrm{~Tb},{ }^{161} \mathrm{Dy},{ }^{163} \mathrm{Dy},{ }^{165} \mathrm{Ho},{ }^{166} \mathrm{Er},{ }^{167} \mathrm{Er},{ }^{169} \mathrm{Tm},{ }^{172} \mathrm{Yb},{ }^{173} \mathrm{Yb}$, and ${ }^{175} \mathrm{Lu}$ in low and high-resolution modes. In addition, we also monitored ${ }^{139} \mathrm{La}$, ${ }^{140} \mathrm{Ce},{ }^{141} \mathrm{Pr},{ }^{143} \mathrm{Nd}$, and ${ }^{145} \mathrm{Nd}$ in low and medium-resolution modes during the analyses. Although many of these isotopes are free of isobaric interferences, monitoring them in medium or high-resolution in addition to low-resolution helps to resolve mass interferences such as those caused by $\mathrm{BaO}^{+}$on the Eu isotopes, and $\mathrm{LREEO}^{+}$on isotopes of the HREEs. The HR-ICP-MS was calibrated with a series of REE calibration standards (i.e., 5, 20, 100, 500, $1000 \mathrm{ng} \mathrm{kg}^{-1}$ ) that were prepared from NIST traceable High Purity Standards (Charleston, SC). Check standards for the REEs were also prepared using Perkin-Elmer multielement solutions. The Canadian Research Council Standard Reference Material (SRM) for estuarine waters (SLEW-3) was analyzed as an additional check for accuracy by comparison to the measured REE values for SLEW-3 reported by Lawrence and Kamber (2006). Analytical precision of REE analyses was always better than $5 \%$ relative standard deviation (RSD), and generally better than $2 \%$ RSD.

\subsection{Geochemical modeling}

Rare earth element solution complexation modeling was carried out for the broad range of ionic strength found in Pettaquamscutt waters $(0.06 \mathrm{M}<I<0.63 \mathrm{M}$; Table 1$)$ by employing a combined specific ion interaction and ion-pairing model initially developed for the REEs by Millero (1992). The model links the specific ion interaction approach (Pitzer, 1979) with an ion pairing model (Garrels and Thompson, 1962; Millero and Schreiber, 1982), thus allowing for the evaluation of REE complexation with inorganic ligands in dilute to highly saline natural waters (Johannesson and Lyons, 1994; Johannesson et al., 1996a,b). The model was updated by adding the most recently determined stability constants for REE complexation with inorganic ligands (Lee and Byrne, 1992; Schijf and Byrne, 1999, 2004; Klungness and Byrne, 2000; Luo and Byrne, 2001, 2004). Free concentrations of inorganic ligands (e.g. $\left[\mathrm{CO}_{3}^{2-}\right]_{F},\left[\mathrm{SO}_{4}^{2-}\right]_{F}$ ) used in solution complexation modeling were computed from the major solute composition of Pettaquamscutt waters via the SpecE8 program of the Geochemist's Workbench ${ }^{8}$ (release 7.0; Bethke, 2008) using the thermodynamic database from PHRQPITZ (thermo_phrqpitz.dat; Plummer et al., 1989), and following the approach outlined by Millero and Schreiber (1982). We did not model REE complexation with naturally occurring organic ligands because previous laboratory investigations (e.g. Sonke and Salters, 2006; Pourret et al., 2007; Marsac et al., 2010; Tang and Johannesson, 2010) were conducted using background electrolyte solutions with ionic strengths less than $0.1 \mathrm{M}$. It is not clear how to correct for ionic strength effects on the activity coefficients of natural organic matter in simulations for the higher salinity waters of the Pettaquamscutt Estuary (Remi Marsac, 2014, pers. comm.; Stephen Lofts, 2014, pers. comm.)

Geochemist's Workbench ${ }^{\circledR}$ (release 7.0; Bethke, 2008) was used to construct a geochemical mixing model to examine the influence of SGD on the shale-normalized REE fractionation patterns of the Pettaquamscutt surface estuary waters. The Lawrence Livermore National Laboratory data base provided with the software (i.e., thermo.dat; Delany and Lundeen, 1989) was modified by adding the 14 naturally occurring REEs and important solution complexation reaction with inorganic ligands (bicarbonate, carbonate, chloride, sulfate, hydroxide, phosphate, and fluoride) using the most up-to-date stability constants (Lee and Byrne, 1992; Schijf and Byrne, 1999, 2004; Klungness and Byrne, 2000; Luo and Byrne, 2001, 2004). To account for solubility limits on REEs we also added the solubility products for the REE-phosphate phases (i.e., $\mathrm{LnPO}_{4} \cdot n \mathrm{H}_{2} \mathrm{O}$ ) determined by Liu and Byrne (1997) to thermo.dat. We assumed that groundwater with a composition identical to groundwater from site A best represents the SGD composition to the surface estuary (Table 4). The composition of Rhode Island Sound waters was modeled using the major solute and REE concentrations of the Station 5 surface water sample, and the Gilbert Stuart Stream endmember was modeled using the measured REE concentrations of this stream and assuming a major ion concentration similar to the Connecticut River (Table 4). This substitution of Connecticut River major ion concentrations is reasonable to a first approximation because broadly similar rock types characterize both drainage basins (Douglas et al., 2002). Previously published phosphate data for groundwater, Gilbert Stuart Stream, and Rhode Island Sound were also employed in the model (Kelly and Moran, 2002; Gaines and Pilson, 1972; Pilson, 1985; Table 4).

\section{Results}

\subsection{REE concentrations}

Rare earth element concentrations for surface and groundwaters from the Pettaquamscutt Estuary are presented in Table 2. Rare earth element concentrations in the groundwaters of the Pettaquamscutt Estuary are generally higher than those of the local surface waters. The only exception is groundwater sample $\mathrm{E}$, which has similar REE concentrations to the mean surface waters of the estuary. Unlike the surface waters of the Pettaquamscutt Estuary, all of which have similar REE concentrations, the groundwaters from the subterranean estuary exhibit a large range in their REE concentrations (Table 2). For example, $\mathrm{Nd}$ concentrations of the groundwaters range from $0.43 \mathrm{nmol} \mathrm{kg}^{-1}$ up to $198 \mathrm{nmol} \mathrm{kg}^{-1}$ (mean $\pm \mathrm{SD}=42.1 \pm 87.2 \mathrm{nmol} \mathrm{kg}^{-1}$; Table 2). By comparison, the Nd concentrations of the surface waters of the estuary range from $259 \mathrm{pmol} \mathrm{kg}^{-1}$ to $649 \mathrm{pmol} \mathrm{kg}^{-1}$ (mean $\pm \mathrm{SD}=421 \pm$

Table 1

Ancillary data for the surface and groundwaters of the Pettaquamscutt Estuary. Major ions, alkalinity, and DOC are in $\mathrm{mmol} \mathrm{kg}^{-1}$. Fe ${ }^{2+}$, total Fe, and S(-II) are in $\mu \mathrm{mol} \mathrm{kg}^{-1}$.

\begin{tabular}{|c|c|c|c|c|c|c|c|c|c|c|c|c|}
\hline & $\mathrm{Na}$ & K & $\mathrm{Mg}$ & $\mathrm{Ca}$ & $\mathrm{Cl}$ & $\mathrm{SO}_{4}^{2-}$ & $\mathrm{pH}$ & Alkalinity & $\mathrm{Fe}^{2+}$ & Total Fe & $\mathrm{S}(-\mathrm{II})$ & DOC \\
\hline \multicolumn{13}{|c|}{ Groundwaters } \\
\hline A & 149 & 3.32 & 20.8 & 2.22 & 179 & 5.47 & 6.49 & 8.41 & $\mathrm{BD}$ & $\mathrm{BD}$ & 9.61 & 0.80 \\
\hline B & 38.3 & 1.14 & 7.12 & 1.36 & 40.2 & 2.95 & 4.78 & 0.08 & 3.58 & 6.45 & 0.125 & 0.38 \\
\hline $\mathrm{C}$ & 154 & 3.13 & 25.9 & 2.44 & 175 & 5.90 & 8.13 & 12.2 & 0.895 & 2.15 & 25.1 & 7.28 \\
\hline $\mathrm{D}$ & 422 & 8.18 & 59.5 & 6.10 & 448 & 24.6 & 6.57 & 10.9 & 0.895 & 1.07 & 27.5 & 6.36 \\
\hline E & 455 & 9.20 & 58.9 & 7.27 & 449 & 24.4 & 7.47 & 2.84 & $\mathrm{BD}$ & 3.58 & 0.717 & 0.44 \\
\hline \multicolumn{13}{|c|}{ Surface waters } \\
\hline Sta. 1 & 225 & 4.60 & 30.4 & 3.49 & 251 & 15.0 & 8.04 & 0.56 & & & & 0.001 \\
\hline Sta. 2 & 333 & 6.94 & 48.3 & 9.96 & 333 & 17.4 & 7.98 & 1.67 & & & & 0.08 \\
\hline Sta. 3 & 332 & 6.49 & 47.2 & 8.84 & 346 & 17.5 & 7.95 & 1.82 & & & & 0.31 \\
\hline Sta. 4 & 428 & 8.57 & 56.9 & 9.82 & 453 & 25.0 & $?$ & 1.13 & & & & 0.15 \\
\hline Sta. 5 & 437 & 9.01 & 55.1 & 5.46 & 460 & 26.9 & 8.04 & 2.28 & & & & 0.18 \\
\hline Mean $^{a}$ & $333 \pm 74$ & $6.84 \pm 1.46$ & $46.8 \pm 9.9$ & $8.66 \pm 2.88$ & $344 \pm 75$ & $18.6 \pm 4.0$ & $7.99 \pm 0.03$ & $1.35 \pm 0.51$ & & & & \\
\hline
\end{tabular}

$\mathrm{BD}$ indicates below detection.

${ }^{a}$ Weighted mean of the surface waters within the Pettaquamscutt Estuary (18.7\% Sta. 1, 54.5\% Sta. 2, 5.1\% Sta. 3, and 21.7\% Sta. 4). 


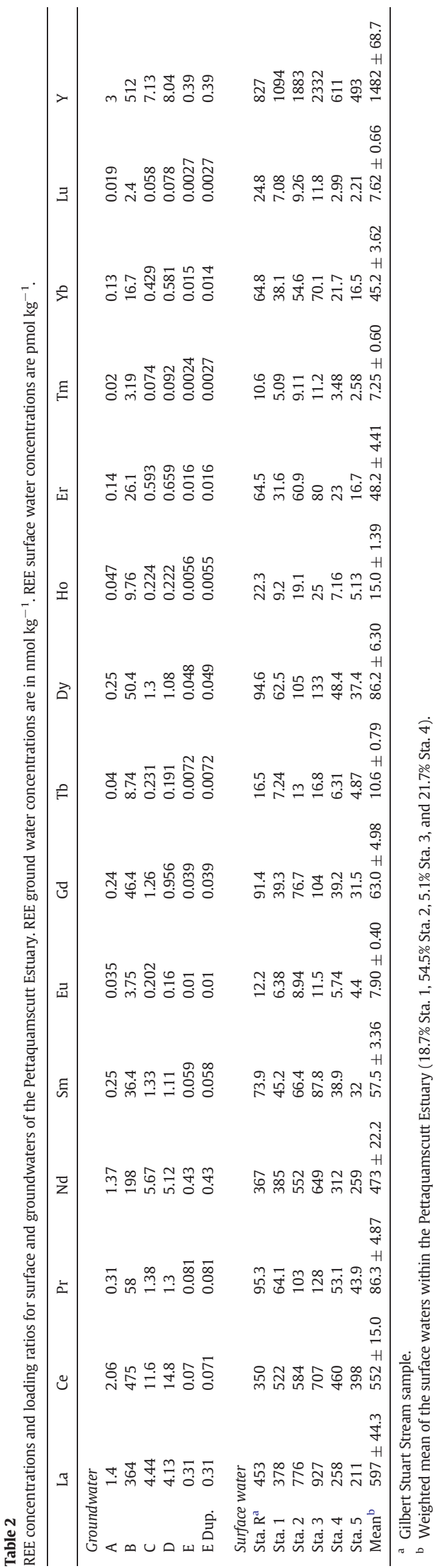

$149 \mathrm{pmol} \mathrm{kg}^{-1}$ ). Therefore, the Nd concentrations of Pettaquamscutt Estuary groundwaters are a factor of 100 greater, on average, than the Nd concentrations of the surface waters.

Surface and groundwater samples from the Pettaquamscutt Estuary have negative Eu anomalies (Table 3 ) that most likely reflect waterrock interactions with the local bedrock and glacial deposits, all of which are also characterized by negative Eu anomalies (e.g., Buma et al., 1971; Taylor and McLennan, 1985; Maria and Hermes, 2001; Dorias, 2003; Schulz et al., 2008; Dorias et al., 2012). Furthermore, it is unlikely that redox conditions are sufficiently reducing in the Pettaquamscutt subterranean estuary to reduce $\mathrm{Eu}^{3+}$ to $\mathrm{Eu}^{2+}$ (Sverjensky, 1984; Middelburg et al., 1988; Leybourne et al., 2006; Leybourne and Johannesson, 2008). In addition, geochemical modeling of $\mathrm{E}_{\mathrm{h}}$ using the SpecE8 and Act1 program of Geochemist's Workbench ${ }^{\circledR}$ (release 7.0; Bethke, 2008) further suggests that the redox conditions are not sufficiently reducing to form $\mathrm{Eu}^{2+}$.

Groundwaters from the Pettaquamscutt subterranean estuary display middle REE (MREE) enriched shale-normalized patterns, with most of the samples having $\mathrm{Gd} / \mathrm{Yb}_{\text {PAAS }}$ and $\mathrm{Gd} / \mathrm{Nd}_{\text {PAAS }}$ ratios greater than 1 (Fig. 2a; Table 3). In contrast, the surface waters generally exhibit flat to slightly HREE enriched, shale-normalized fractionation patterns (Fig. 2b; Table 3). The shale-normalized REE pattern of groundwater sample E near the outflow of the Pettaquamscutt Estuary to Rhode Island Sound exhibits an "M-shaped" pattern with depleted HREEs and LREEs, positive Nd and Dy "anomalies", and a concave upwards pattern between Nd and Dy (Fig. 2c). Duplicate analyses of groundwater E produced identical, shale-normalized REE patterns, indicating that the unusual REE fractionation pattern of groundwater $\mathrm{E}$ is indeed characteristic of groundwater from this location. The shale-normalized REE pattern of groundwater sample E is similar to Narragansett Bay water collected from the surf zone at Station 5 (Sta. 5), approximately $0.2 \mathrm{~km}$ to the southeast (Figs. 1 and 2). Specifically, the shalenormalized REE pattern of Sta. 5 water also exhibits HREE and LREE depletions and positive Nd and Dy "anomalies". Furthermore, the "M-shaped" shale-normalized REE patterns of the Sta. 5 water and groundwater E differ from the HREE enriched coastal seawater of Buzzard's Bay and Long Island Sound (Elderfield and Sholkovitz, 1987; Sholkovitz et al., 1989; Fig. 2).

\subsection{REE solution complexation}

The results for the REE solution complexation modeling for the surface and groundwaters of the Pettaquamscutt Estuary are presented

Table 3

Shale-normalized fractionation factors, $\mathrm{Ce}-\left(\mathrm{Ce} / \mathrm{Ce}^{*}\right)$, and Eu-anomalies $\left(\mathrm{Eu} / \mathrm{Eu}^{*}\right)$ for surface and groundwaters of the Pettaquamscutt Estuary.

\begin{tabular}{|c|c|c|c|c|}
\hline & $(\mathrm{Gd} / \mathrm{Nd})_{\text {PAAS }}$ & $(\mathrm{Gd} / \mathrm{Yb})_{\mathrm{PAAS}}$ & $\mathrm{Ce} / \mathrm{Ce}^{*}$ & $\mathrm{Eu} / \mathrm{Eu}^{*}$ \\
\hline \multicolumn{5}{|c|}{ Groundwater } \\
\hline A & 1.46 & 1.17 & 0.72 & 0.61 \\
\hline B & 1.95 & 1.69 & 0.74 & 0.38 \\
\hline C & 1.85 & 1.78 & 1.06 & 0.67 \\
\hline D & 1.55 & 1.00 & 1.45 & 0.68 \\
\hline $\mathrm{E}$ & 0.74 & 1.60 & 1.01 & 0.94 \\
\hline E Dup. & 0.74 & 1.62 & 1.01 & 0.92 \\
\hline \multicolumn{5}{|c|}{ Surface water } \\
\hline Sta. $\mathrm{R}^{\mathrm{a}}$ & 2.07 & 0.85 & 0.39 & 0.62 \\
\hline Sta. 1 & 0.85 & 0.62 & 0.76 & 0.66 \\
\hline Sta. 2 & 1.16 & 0.85 & 0.46 & 0.53 \\
\hline Sta. 3 & 1.33 & 0.90 & 0.46 & 0.51 \\
\hline Sta. 4 & 1.04 & 1.10 & 0.90 & 0.63 \\
\hline Sta. 5 & 1.01 & 1.16 & 0.95 & 0.60 \\
\hline Mean $^{\mathrm{b}}$ & 1.08 & 0.86 & 0.61 & 0.58 \\
\hline
\end{tabular}

$\mathrm{Ce} / \mathrm{Ce}^{*}=\mathrm{Ce}_{\text {PAAS }} /\left(0.5 \times \mathrm{La}_{\text {PAAS }}+0.5 \times \operatorname{Pr}_{\text {PAAS }}\right)$.

$\mathrm{Eu} / \mathrm{Eu}^{*}=\mathrm{Eu}_{\mathrm{PAAS}} /\left(0.5 \times \mathrm{Sm}_{\mathrm{PAAS}}+0.5 \times \mathrm{Tb}_{\mathrm{PAAS}}\right)$.

PAAS $=$ Post-Archean Australian Shale composite.

a Gilbert Stuart Stream.

b Weighted mean of the surface waters within the Pettaquamscutt Estuary (18.7\% Sta. 1, $54.5 \%$ Sta. 2, 5.1\% Sta. 3, and 21.7\% Sta. 4). 


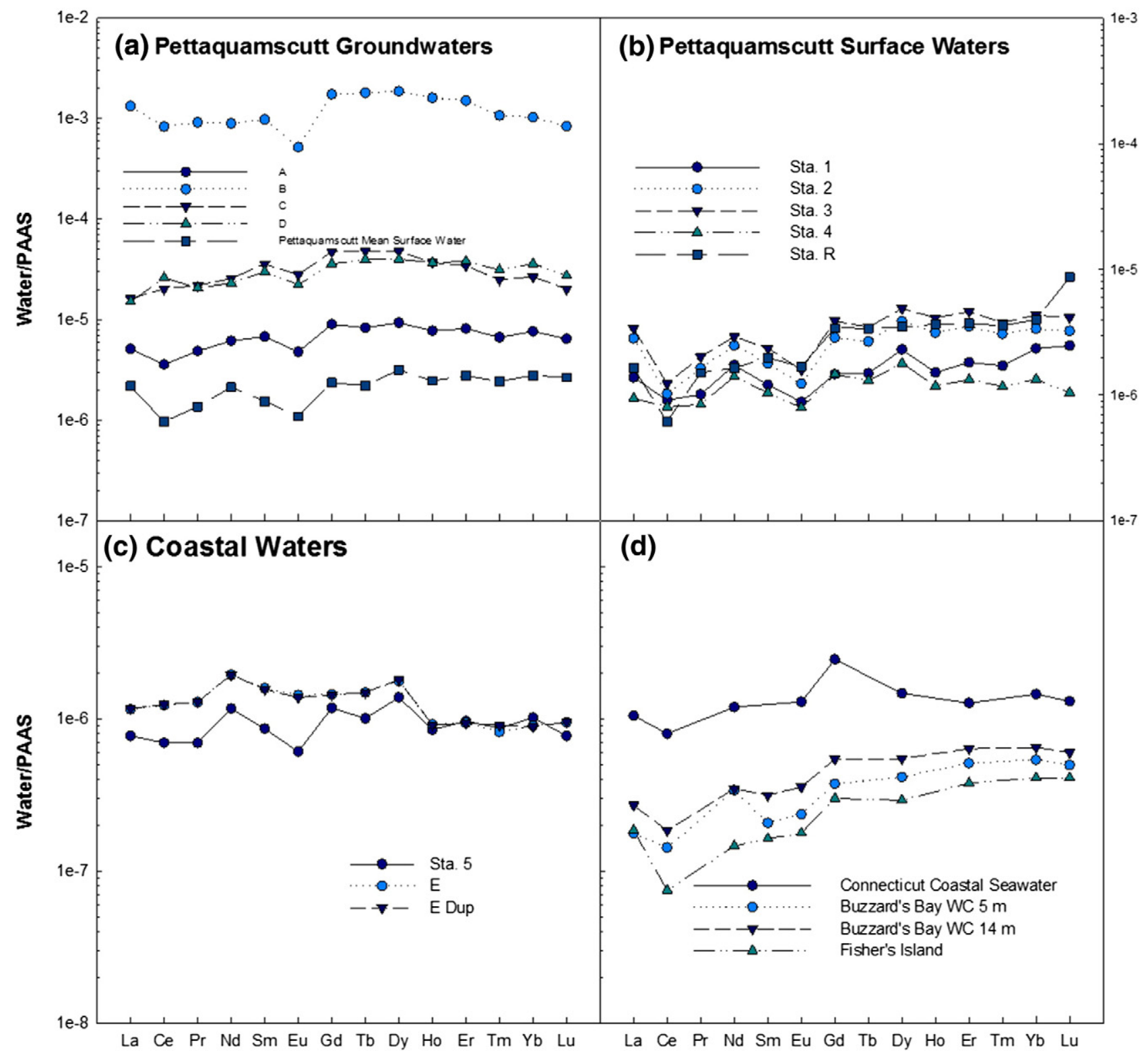

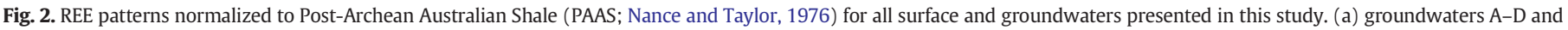

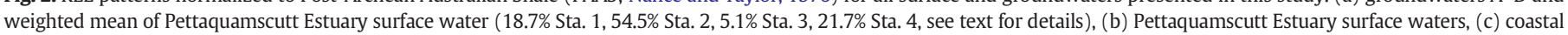

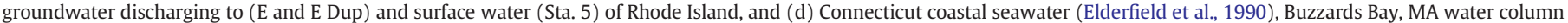
(Sholkovitz et al., 1989), and Fisher's Island (Long Island Sound; Elderfield and Sholkovitz, 1987).

in Fig. 3. As mentioned above, major element data used in the model calculations are given in Table 1. Model predictions for the majority of the Pettaquamscutt waters suggest that REEs are predominately complexed with carbonate ions. For example, for groundwaters A and D, which have $\mathrm{pH}$ values of 6.49 and 6.57 , respectively, the model predicts that carbonato complexes (i.e., $\mathrm{LnCO}_{3}^{+}$, where $\mathrm{Ln}$ indicates any of the 14 naturally occurring lanthanides) predominate, accounting for $38 \%$ to $58 \%$ and $46 \%$ to $64 \%$, respectively, of each REE in solution (Fig. 3). The free metal ion, $\mathrm{Ln}^{3+}$, is also predicted to be important in these groundwaters, especially in the case of La, accounting for as much as $40 \%$ of La in solution. For groundwaters $C$ and E, Pettaquamscutt surface waters, and Sta. 5 surface waters, the model predicts that REEs occur as both the carbonato and dicarbonato complexes [i.e., $\operatorname{Ln}\left(\mathrm{CO}_{3}\right)_{2}^{-}$] in solution (Fig. 3). Generally, dicarbonato complexes are predicted to increase in importance with increasing $\mathrm{pH}$ of the subterranean and surface estuary waters (Fig. 3). For example, groundwater $\mathrm{C}$ has the highest measured $\mathrm{pH}$ of the Pettaquamscutt Estuary waters sampled ( $\mathrm{pH}$ 8.13; Table 1), and the model predicts that the REEs chiefly occur in this groundwater as dicarbonato complexes (Fig. 3). As $\mathrm{pH}$ decreases, the relative amount of each REE complexed as dicarbonato ions decreases as the relative amount of each REE occurring as carbonato complexes increases (Fig. 3). The primary exception is the acidic groundwater B sample ( $\mathrm{pH}$ 4.78) where the model predicts that REEs chiefly occur in solution as free metal ion species, followed by sulfate complexes (Fig. 3). We did not attempt to evaluate the possibility that REEs occur in Pettaquamscutt Estuary groundwaters or surface waters complexed to natural organic matter because it is not clear how to correct for ionic strength effects on activity coefficients for natural organic matter in simulations conducted for near seawater salinities.

\section{Discussion}

\subsection{Controls on REE in Pettaquamscutt groundwater}

Groundwaters from the Pettaquamscutt subterranean estuary are characterized by MREE-enriched shale-normalized fractionation 
patterns [i.e., $0.74 \leq(\mathrm{Gd} / \mathrm{Nd})_{\text {PAAS }} \leq 1.95 ; 1.0 \leq(\mathrm{Gd} / \mathrm{Yb})_{\text {PAAS }} \leq 1.78$ ] negative Eu anomalies [0.19 $\left.\leq \mathrm{Eu} / \mathrm{Eu}^{*} \leq 0.47\right]$, and both small negative and positive Ce anomalies [0.72 $\left.\leq \mathrm{Ce} / \mathrm{Ce}^{*} \leq 1.45\right]$ (Fig. 2, Table 3 ). The MREEenriched fractionation patterns could reflect a number of processes including geochemical reactions occurring within the Pettaquamscutt subterranean estuary between groundwater and aquifer minerals (e.g., mineral dissolution/precipitation, ion-exchange), salt-induced coagulation and removal of REE-bearing Fe-organic colloids, or aqueous complexation with ligands not included in the REE complexation model (e.g., humic substances). Examining aqueous complexation first, previous studies demonstrate that the predominate ligands complexing REEs are dependent upon solution chemistry, especially $\mathrm{pH}$; therefore, the changes in solution composition that can occur along groundwater flow paths can result in changes in solution complexation of REEs and presumably the REE fractionation patterns (Johannesson et al., 1999, 2005; Dia et al., 2000; Tang and Johannesson, 2006; Tweed et al., 2006; Willis and Johannesson, 2011). A remarkable feature of the Pettaquamscutt subterranean estuary is that the wide $\mathrm{pH}$ range $(4.78 \leq \mathrm{pH} \leq 8.13$; Table 1 ) exhibited by local groundwaters does not appear to correlate with differences in the shapes of the shalenormalized REE patterns, despite the differences in the predicted aqueous complexation of the REEs in these groundwaters (Figs. 2 and 3). For example, shale-normalized $(\mathrm{Gd} / \mathrm{Nd})_{\text {PAAS }}$ and $(\mathrm{Gd} / \mathrm{Yb})_{\text {PAAS }}$ ratios for the acidic (i.e., pH 4.78) groundwater $\mathrm{B}$ are similar to those of alkaline (i.e., $\mathrm{pH} 8.13$ ) groundwater C (1.95 and 1.69 vs. 1.85 and 1.78 , respectively; Table 3). The fact that groundwaters from the Pettaquamscutt subterranean estuary all exhibit broadly similar, MREE-enriched shale-normalized fractionation patterns independent of $\mathrm{pH}$, and hence inorganic aqueous complexation, suggests that solution complexation reactions do not directly control the shale-normalized REE patterns of these groundwaters. Nevertheless, solution composition in terms of $\mathrm{pH}$ does appear to impart controls on the concentrations of REEs in Pettaquamscutt Estuary groundwaters, as REE concentrations are greatest in the acidic groundwater $(\mathrm{pH} 4.78)$ from location $\mathrm{B}$ (Table 2). Specifically, the Nd concentration of groundwater B is $198 \mathrm{nmol} \mathrm{k^{-1 }}$ compared to a mean \pm SD Nd concentration of $3.15 \pm 2.63 \mathrm{nmol} \mathrm{kg}{ }^{-1}$ for the other Pettaquamscutt groundwaters, which exhibit a mean \pm SD pH of $7.15 \pm 0.8$. Many other researchers (Johannesson et al., 1999, 2005; Dia et al., 2000; Tang and Johannesson, 2006; Tweed et al., 2006; Willis and Johannesson, 2011) have noted the importance that $\mathrm{pH}$ plays in overall REE concentrations in natural waters although it is recognized that the common inverse relationship between $\mathrm{pH}$ and REE concentrations is complicated by the presence of colloidal materials in natural waters (Goldstein and Jacobsen, 1987, 1988a; Elderfield et al., 1990).

Salt-induced coagulation of Fe-rich, organic colloids is recognized as a major process that removes Fe and other trace elements, including the REEs, as fresh river water mixes with seawater in surface estuaries (e.g., Sholkovitz, 1976, 1978, 1992, 1993, 1995; Boyle et al., 1977; Goldstein and Jacobsen, 1988b). The colloidal pool of REEs in many rivers exhibits MREE-enriched patterns when normalized to shale composites (Elderfield et al., 1990; Åström and Corin, 2003; Stolpe et al., 2013). Because we did not filter Pettaquamscutt Estuary surface or groundwaters through filters with nominal pore sizes less than $0.45 \mu \mathrm{m}$, we cannot explicitly address the possible role that colloids may play in influencing the REE concentrations and fractionation patterns of the Pettaquamscutt Estuary waters. Nevertheless, REE removal via colloid coagulation in surface estuaries fractionates the REEs as the LREEs are preferentially scavenged compared to the HREEs during the process (Elderfield et al., 1990; Sholkovitz, 1992, 1995). Hence, saltinduced colloid coagulation and the resulting REE removal from solution in low- to mid-salinity regions of surface estuaries lead to shale-normalized REE patterns for the waters that are strongly enriched in the HREEs. The fact that we see no fractionation of the REEs with increasing salinity in the Pettaquamscutt subterranean estuary, but do observe a decrease in REE concentrations with increasing salinity and $\mathrm{pH}$ (e.g., $\mathrm{r}=-0.67$ for $\mathrm{Nd}$ vs. $\mathrm{Cl}^{-}$; Fig. 4), suggests that salt-induced colloid coagulation is either not important in the subterranean estuary, or if it is occurring, it does not fractionate the REEs. In either case, additional field and laboratory investigations are required to address these issues.

Therefore, we suggest that the MREE-enriched, shale-normalized fractionation patterns that characterize groundwater from the Pettaquamscutt Estuary likely reflect geochemical reactions occurring in the subterranean estuary between the groundwater and aquifer minerals. One possible mineral phase influencing the shale-normalized REE patterns of Pettaquamscutt groundwaters is apatite (Tricca et al., 1999; Aubert et al., 2001; Hannigan and Sholkovitz, 2001). Both biogenic and igneous apatites commonly exhibit enrichments in the MREEs when normalized to shale composites such as PAAS (Hanson, 1980; Gromet and Silver, 1983; Wright et al., 1984, 1987; Grandjean and Albarède, 1989; Grandjean-Lécuyer et al., 1993; Kemp and Truemann, 2003; Leybourne and Johannesson, 2008). Moreover, apatite is a common accessory mineral in both the Esmond Igneous Suite and the Narragansett Pier Granite (Hermes et al., 1994), and is expected to be present as a trace mineral in the local glacial deposits. The solubility of apatite increases with decreasing $\mathrm{pH}$, and becomes substantial at $\mathrm{pH}$ less than 7 (Chairrat et al., 2007). Consequently, apatite in contact with groundwaters $\mathrm{A}, \mathrm{B}$, and $\mathrm{D}$, all of which have $\mathrm{pH}<7$, is expected to be susceptible to dissolution reactions. Because the $\mathrm{pH}$ of groundwaters in the Pettaquamscutt region is generally acidic (Rosenhein et al., 1968; Tim Cranston, 2013, pers. comm.), conditions are expected to be suitable for apatite dissolution within the surficial aquifer, especially where the aquifer is recharged. Specifically, infiltration of acidic meteoric precipitation in conjunction with increased dissolved $\mathrm{CO}_{2}$ in soil zone waters, owing to microbial respiration, can push the $\mathrm{pH}$ of recharge waters to less than 5, which would favor apatite dissolution (Drever, 1997). Apatite dissolution is not favored for groundwaters $\mathrm{C}$ and $\mathrm{E}$, which have more alkaline pH values (Table 1 ); however, the REEs could have been released into the groundwater upgradient of the sampling locations. Instead, for these more alkaline groundwaters, the microbial breakdown of organic material into organic acids may subsequently facilitate apatite weathering (e.g., Taunton et al., 2000a,b; Welch et al., 2002). The relative enrichment of MREEs in Pettaquamscutt groundwaters by apatite weathering may be further enhanced by the precipitation of LREE bearing, secondary phosphate minerals such as rhabdophane and florencite (Banfield and Eggleton, 1987; Braun et al., 1990, 1998). For example, during rhabdophane precipitation, the LREEs between Ce and Eu are preferentially removed from solution relative to heavier REEs (Köhler et al., 2005).

Because many natural waters, including seawater, are saturated with respect to REE-phosphate coprecipitates (i.e., $\mathrm{LnPO}_{4} \cdot n \mathrm{H}_{2} \mathrm{O}$ ), a number of researchers have argued that dissolved REE concentrations are limited by the solubility of these phases (Jonasson et al., 1985; Byrne and Kim, 1993; Johannesson et al., 1995). Using REE-phosphate solubility product data from Liu and Byrne (1997) and dissolved inorganic phosphorus data for Pettaquamscutt groundwaters (Kelly and Moran, 2002) and surface waters (Gaines and Pilson, 1972), we computed saturation indices for Pettaquamscutt Estuary groundwaters using Geochemist's Workbench ${ }^{\circledR}$ (release 7.0; Bethke, 2008). The model calculations indicate that groundwaters discharging to the Pettaquamscutt Estuary are all supersaturated with respect to the LREE- 


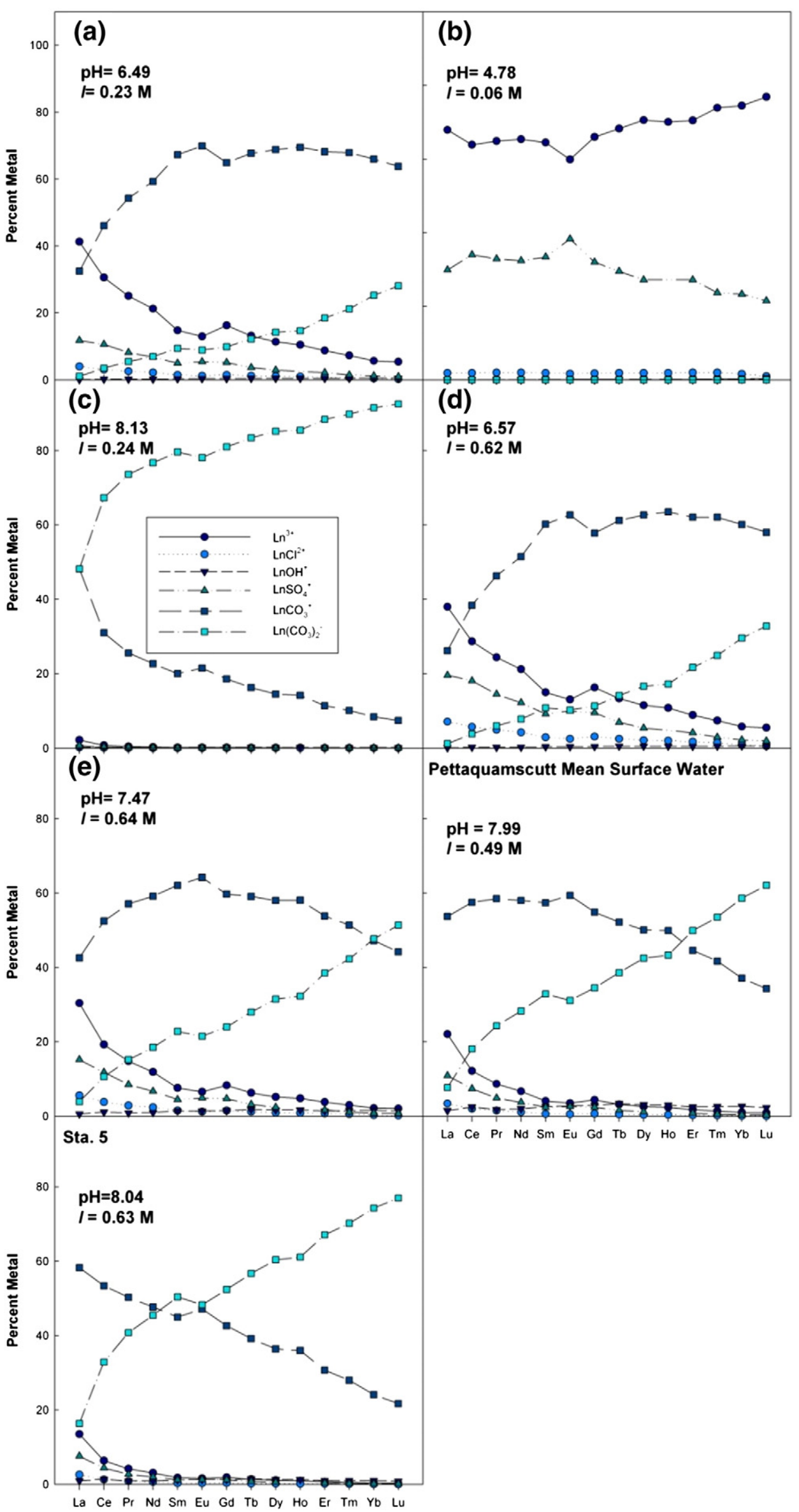



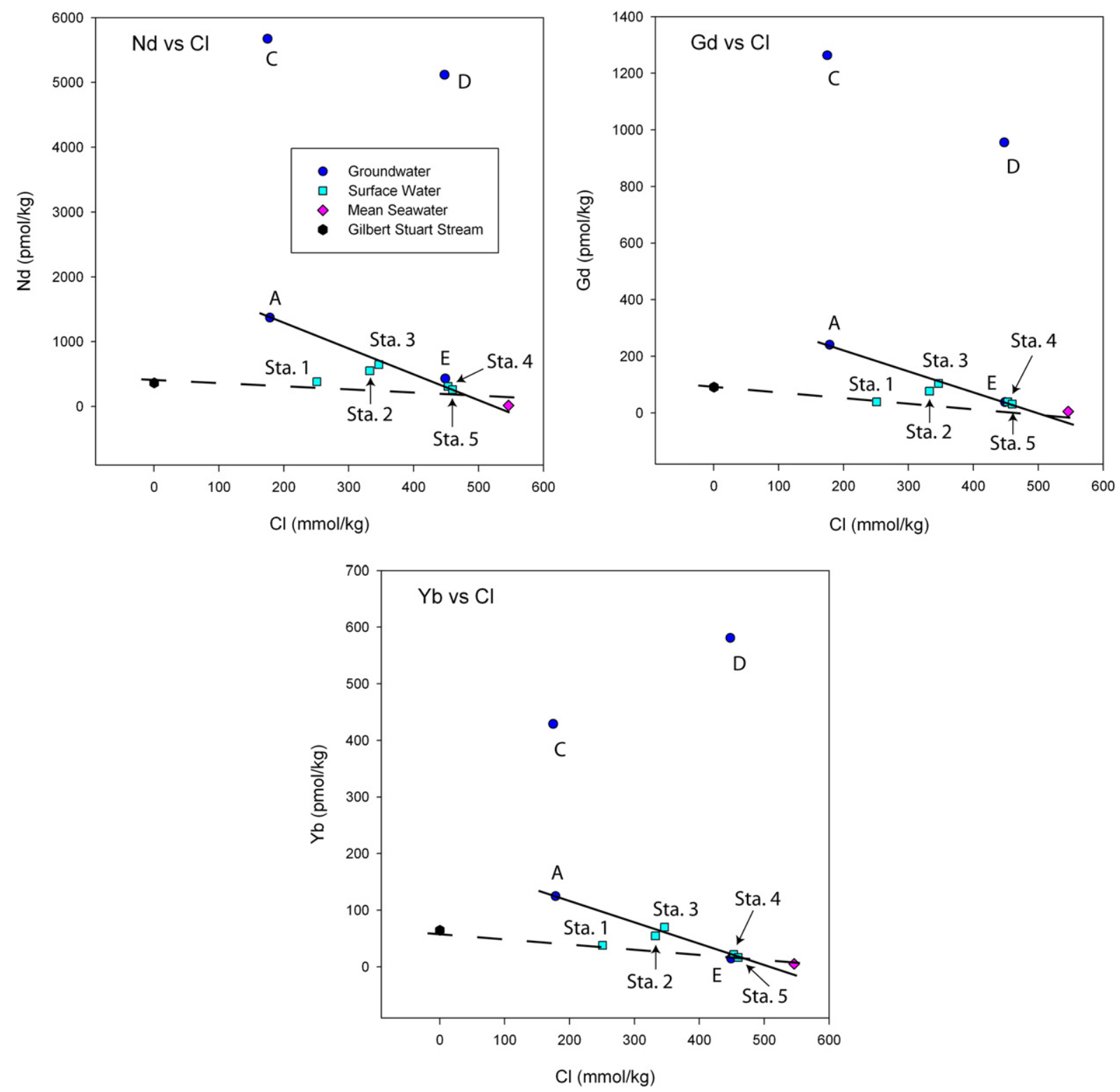

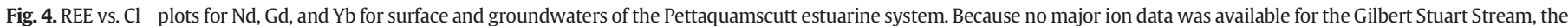

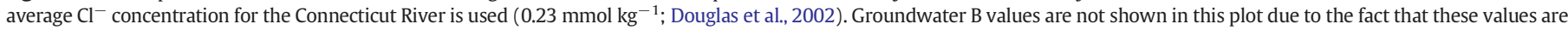

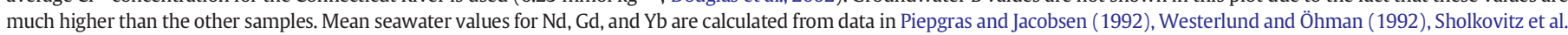

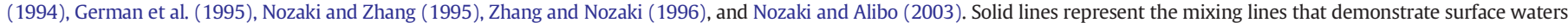

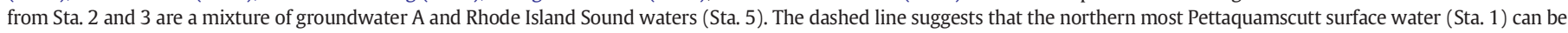
explained as an 50:50 mix of Gilbert Stuart Stream and Rhode Island Sound (Sta. 5).

and MREE-phosphate coprecipitates (i.e., $\mathrm{LnPO}_{4} \cdot n \mathrm{H}_{2} \mathrm{O}$ ) and groundwater sample $A$ is also supersaturated with respect to HREE-phosphate minerals of the same form. In addition, all the Pettaquamscutt Estuary groundwaters, except for sample B and D, are supersaturated with respect to hydroxyapatite $(\log (\mathrm{SI})$ values of $0.037,4.21$, and 7.36 for $\mathrm{A}, \mathrm{C}$, and $\mathrm{E}$, respectively). Although fluorapatite is the most common form of apatite in the environment (Deer et al., 1992; Klein, 2002), because we did not measure $\mathrm{F}^{-}$concentrations in the Pettaquamscutt waters, we cannot evaluate the saturation indices for this mineral. Nevertheless, we interpret the supersaturation of Pettaquamscutt Estuary groundwaters with respect to hydroxyapatite as evidence that these waters are also likely supersaturated with respect to fluorapatite. Taken together the saturation index calculations suggest that REE-phosphate minerals like rhabdophane and florencite, and/or REE-bearing apatite, control the solubility limits of the REEs in groundwaters from the Pettaquamscutt subterranean estuary.
Anthropogenic phosphorus may also influence the REE patterns of the Pettaquamscutt groundwaters by enhancing the precipitation of phosphate minerals. Wastewater from industrial activities in the Narragansett Bay has added excess phosphorus to the waters for 200 years (Nixon et al., 2008). Although industry in the region has decreased since its height during the early to mid-20th century, septic tanks, which are another source of phosphorus, are used extensively in the region for residential waste disposal (Nixon et al., 2008). The addition of phosphorus that escapes from septic tanks into local groundwaters could potentially enhance the LREE removal from groundwaters relative to MREEs and HREEs because: 1) LREEs are typically more abundant than MREEs and HREEs; and 2) the solubility products for LREE-phosphates are lower than the corresponding MREE- and HREE-phosphates (Jonasson et al., 1985; Liu and Byrne, 1997; Centiner et al., 2005).

Another process that likely exerts important controls on dissolved REE concentrations in the Pettaquamscutt subterranean estuary is the 
reductive dissolution of $\mathrm{Fe}(\mathrm{III})$ oxides/oxyhydroxides contained within the sediments. Previous work has demonstrated that Fe(III) oxides/ oxyhydroxides can exhibit MREE enriched, shale-normalized REE fractionation patterns, and as a consequence, reductive dissolution of these mineral phases could impart a MREE enriched signature to the waters by releasing relatively more of the MREEs compared to LREEs and HREEs upon dissolution (Johannesson and Lyons, 1995; Johannesson and Zhou, 1999; Protano and Riccobono, 2002). Furthermore, positive Ce anomalies found in groundwater samples C and D may be evidence for the reductive dissolution of $\mathrm{Fe}$ (III) oxides/ oxyhydroxides due to the fact that positive Ce anomalies are noted in marine ferromanganese crusts and nodules (Elderfield, 1988; Byrne and Sholkovitz, 1996; Bau, 1999). Rare earth elements in groundwaters from the Pettaquamscutt Estuary correlate well with dissolved $\mathrm{Fe}^{2+}$ $\left(\mathrm{R}^{2}\right.$ value of 0.97 for $\mathrm{Nd}, \mathrm{Gd}$, and Yb; Tables 1 and 2 ) but exhibit weaker relationships with total dissolved Fe ( $\mathrm{R}^{2}$ value of 0.70 for $\mathrm{Nd}, \mathrm{Gd}$, and $\mathrm{Yb}$ Tables 1 and 2). These correlations, however, are controlled solely by one sample with much higher REE concentrations (groundwater B). High DOC values in groundwater samples $C$ and D may inhibit the precipitation of Fe-sulfide minerals by the formation of Fe-organic complexes (Luther et al., 1992), which further complicates the interpretation of these relationships. Geochemical modeling employing Geochemist's Workbench ${ }^{\circledR}$ (release 7.0; Bethke, 2008) suggests that groundwaters $C$ and $D$ are supersaturated with respect to Fe-sulfides yet they have the highest dissolved sulfide concentrations. We interpret the strong positive correlation of $\mathrm{S}(-\mathrm{II})$ and DOC $\left(\mathrm{R}^{2}=0.92\right.$; Table 1$)$ in the Pettaquamscutt groundwaters as evidence for the inhibition of Fe-sulfide precipitation by Fe-organic complexation.

\subsection{Controls on REE in surface waters}

The shale-normalized REE fractionation patterns of Pettaquamscutt surface waters and plots of individual REE concentrations as a function of $\mathrm{Cl}^{-}$concentrations, all suggest that mixing of SGD, Gilbert Stuart Stream waters, and Rhode Island Sound waters occurs within the surface estuary (Figs. 2 and 4). Moreover, except for Station 1, the surface waters of the Pettaquamscutt Estuary fall along mixing lines when individual REEs are plotted vs. the corresponding $\mathrm{Cl}^{-}$concentrations. Here we use either Gilbert Stuart Stream water or groundwater A as the freshwater endmembers and Rhode Island Sound as the marine endmember (i.e., the Station 5 water; Fig. 4). The REE data are also consistent with the Pettaquamscutt Estuary not being well mixed over its entire length. Specifically, the REE data suggest that surface waters from Stations 2 and 3 are mixtures of equal parts groundwater $A$ and Rhode Island Sound water (Station 5), but surface water at Station 4 is dominated by the influx of water from Rhode Island Sound (Fig. 4). Kelly and Moran (2002) noted that the residence time of water north of Station 3 was greater than the tidal cycle, whereas surface waters south of Station 3 are well-mixed due to complete water exchange over one tidal cycle. The observations of Kelly and Moran (2002) and those presented in this study are in agreement with the general structure of the Pettaquamscutt Estuary, which consists of a northern, fjord-like portion (north of Station 3 ) that contains two deep ( 15$20 \mathrm{~m}$ ), anoxic saline basins that do not mix with the estuary except during relatively rare overturn events, and a shallow $(<2 \mathrm{~m})$ southern portion that is well mixed (Gaines and Pilson, 1972). The surface water at Station 1 falls in the middle of the mixing line between the Gilbert Stuart Stream and Rhode Island Sound waters (Fig. 4), which likely reflects the proximity of Station 1 to the mouth of the Gilbert Stuart Stream (Fig. 1).

Based on the geographic distribution of the glacial deposits (see Schafer, 1961a,b; Nowicki and Gold, 2008), as well as the cross plots for $\mathrm{Nd}, \mathrm{Gd}$, and $\mathrm{Yb}$, as a function of $\mathrm{Cl}^{-}$concentrations, we suggest that groundwater discharging to the northwestern portions of the Pettaquamscutt Estuary (groundwater A) accounts for the majority of the SGD to this estuary. Groundwater A is the only groundwater sample from the subterranean estuary that plots along the mixing line for the Pettaquamscutt Estuary (Fig. 4). Groundwaters from both sites $C$ and $\mathrm{D}$ have REE concentrations that plot well above the mixing line indicating that these groundwaters, despite their high REE concentrations, likely contribute little to the REE budget of the Pettaquamscutt Estuary. The variation in the physical characteristics of the surficial aquifer materials may explain why only groundwater A appears to influence the REE budget of the surface estuary waters. Specifically, in the northwest portion of the Pettaquamscutt Estuary from where groundwater A was collected, surficial sediments are composed of highly permeable glacial outwash deposits and undifferentiated ice contact deposits consisting of poorly sorted gravel, cobbles, and pebbles (Schafer, 1961a; Nowicki and Gold, 2008). In contrast, the eastern and southern portions of the estuary where groundwaters $C$ and D were collected are underlain by a ground moraine deposit composed of compacted till (Schafer, 1961b; Nowicki and Gold, 2008). The compacted till contains gravel, sand, and silt, which specifically makes it less permeable than the glacial outwash and undifferentiated ice contact deposits of the northwestern portion of the Pettaquamscutt watershed.

We performed two different simulations, one for the northern, fjordlike portion of the estuary, and the other for the well-mixed southern part of the estuary. In each case the simulations were set up to reproduce the REE concentrations and shale-normalized REE fractionation patterns of Pettaquamscutt Estuary surface waters from the northern (Stations 2 and 3) and southern (Station 4) parts of the estuary by mixing groundwater A, Gilbert Stuart Stream, and Rhode Island Sound (i.e., Station 5) waters in various proportions (Table 4). For both model simulations, equal portions of groundwater A and Gilbert Stuart Stream water were used because Kelly and Moran (2002) reported that the volume of groundwater discharged to the Pettaquamscutt is roughly equal to the volumetric discharge from the Gilbert Stuart Stream. Rhode Island Sound water was subsequently titrated into various mixtures of equal proportions of groundwater A and Gilbert Stuart Stream to best reproduce the shale-normalized REE patterns of surface

\section{Table 4}

Major element and REE data employed in the mixing model in the form entered into the React Program of the Geochemist's Workbench ${ }^{\circledR}$ (release 7.0; Bethke, 2008). Major element concentrations are all in $\mathrm{mmol} \mathrm{kg}^{-1}$ except for $\mathrm{P}\left(\mu \mathrm{mol} \mathrm{kg} \mathrm{kg}^{-1}\right)$. REE concentrations of Groundwater A are in nmol kg-1. Surface water REE concentrations (Gilbert Stuart Stream and Rhode Island Sound) are in $\mathrm{pmol} \mathrm{kg}^{-1}$.

\begin{tabular}{|c|c|c|c|}
\hline & Groundwater $A^{a}$ & Gilbert Stuart Stream ${ }^{\mathrm{b}}$ & Rhode Island Sound ${ }^{\mathrm{c}}$ \\
\hline $\mathrm{pH}$ & 6.49 & 6.89 & 8.04 \\
\hline $\mathrm{Ca}$ & 2.22 & 0.35 & 5.46 \\
\hline $\mathrm{Mg}$ & 20.8 & 0.28 & 55.1 \\
\hline $\mathrm{Na}$ & 149 & 0.03 & 437 \\
\hline K & 3.32 & 0.03 & 9.01 \\
\hline $\mathrm{Cl}$ & 179 & 0.23 & 460 \\
\hline $\mathrm{HCO}_{3}^{-}$ & 8.41 & 0.69 & 2.28 \\
\hline $\mathrm{SO}_{4}^{2-}$ & 5.47 & 0.072 & 26.9 \\
\hline $\mathrm{P}$ & 1.96 & 0.63 & 1.23 \\
\hline $\mathrm{La}$ & 1.40 & 453 & 211 \\
\hline $\mathrm{Ce}$ & 2.06 & 350 & 398 \\
\hline Pr & 0.31 & 95.3 & 43.9 \\
\hline Nd & 1.37 & 367 & 259 \\
\hline Sm & 0.25 & 73.9 & 32 \\
\hline $\mathrm{Eu}$ & 0.035 & 12.2 & 4.4 \\
\hline Gd & 0.24 & 91.4 & 31.5 \\
\hline $\mathrm{Tb}$ & 0.04 & 16.5 & 4.87 \\
\hline Dy & 0.25 & 94.6 & 37.4 \\
\hline Ho & 0.047 & 22.3 & 5.13 \\
\hline $\mathrm{Er}$ & 0.14 & 64.5 & 16.7 \\
\hline $\mathrm{Tm}$ & 0.02 & 10.6 & 2.58 \\
\hline $\mathrm{Yb}$ & 0.13 & 64.8 & 16.5 \\
\hline Lu & 0.019 & 24.8 & 2.21 \\
\hline
\end{tabular}

a P concentration is from Kelly and Moran (2002).

b Major element data is average Connecticut River values from Douglas et al. (2002). P data is from Gaines and Pilson (1972).

c Major element and REE data from Sta. 5 are used for Rhode Island Sound. P data for Rhode Island are the values reported by Pilson (1985) for Narragansett Bay. 
waters of the northern and southern parts of the Pettaquamscutt Estuary. Because of the differences in the hydrodynamics between the northern, fjord-like and southern well-mixed parts of the estuary, the mixing models required substantially different amounts of Rhode Island Sound water to best reproduce the shale-normalized REE patterns of Pettaquamscutt Estuary waters.

Fig. 5 presents the results of the mixing simulations. A satisfactory match for the majority of the REEs (i.e., MREEs and HREEs) was obtained for the northern, fjord-like part of the Pettaquamscutt Estuary by employing a mixture of 25\% groundwater A, 25\% Gilbert Stuart Stream, and 50\% Rhode Island Sound water (Fig. 5a). Here, the average REE concentration of surface waters from Stations 2 and 3 was used in the model. The model does a good job of reproducing the MREE and HREE concentrations and their associated, shale-normalized ratios, but performs poorly for the LREEs (i.e., La-Sm). Nonetheless, the enhanced removal of the LREE predicted by the model is not entirely unexpected owing to the much lower solubility product values for the LREEphosphate phases compared to the MREE- and HREE-phosphate phases (Liu and Byrne, 1997). The possible reasons for the discrepancy in the removal of LREEs by phosphate phases between the mixing model and the actual data are discussed below.

The mixing model for the southern portion of the Pettaquamscutt Estuary was performed identically as for the northern part except that the mixing proportions of the three endmembers required to best reproduce the REE concentrations and shale-normalized REE patterns of surface water from Station 4 were substantially different than for surface waters from the northern part of the estuary. Specifically, the best match was obtained for a mixture of $2.5 \%$ groundwater A, 2.5\% Gilbert Stuart Stream, and 95\% Rhode Island Sound water (Fig. 5b). Again, the mixing simulation was unable to match the LREE

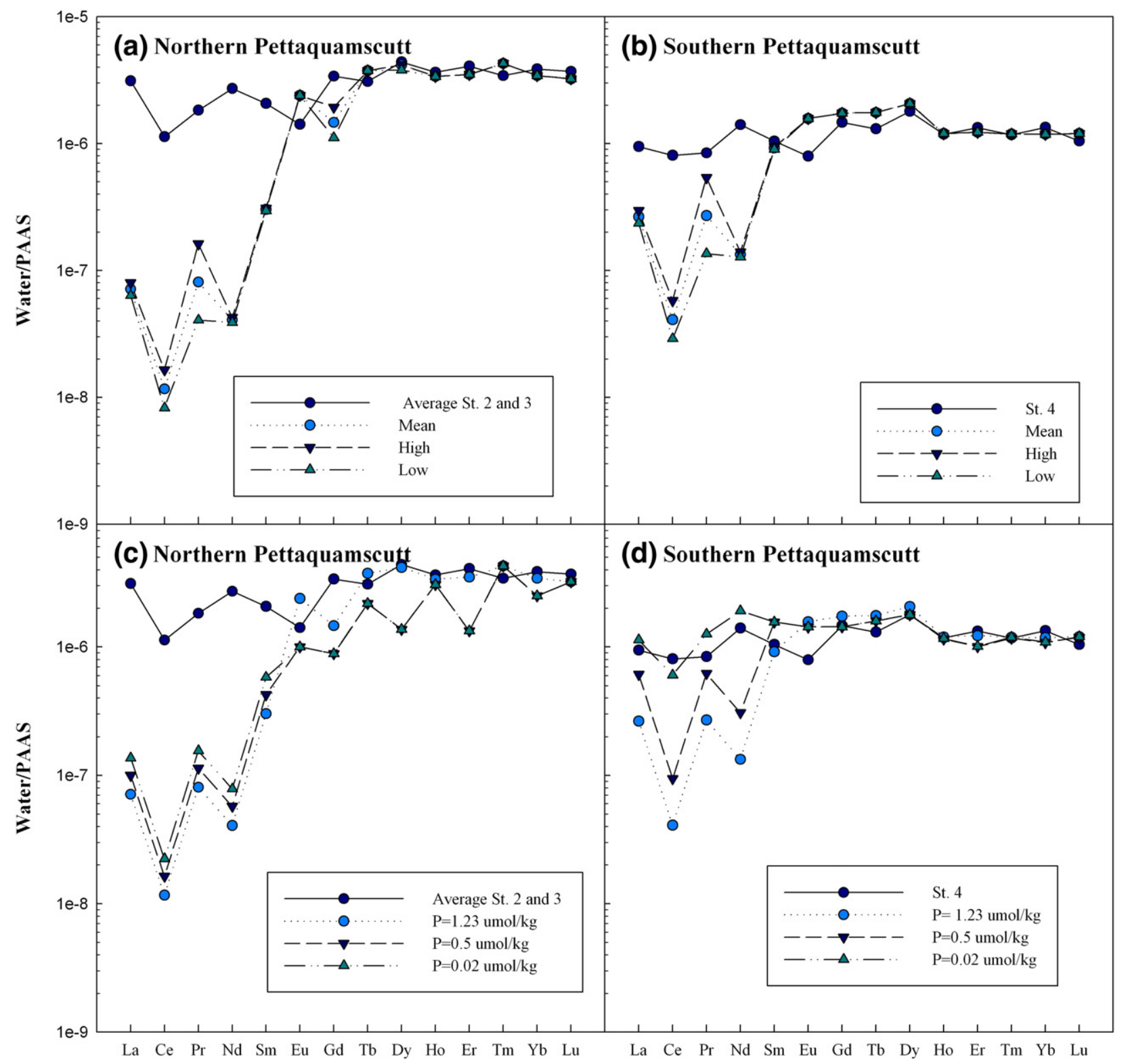

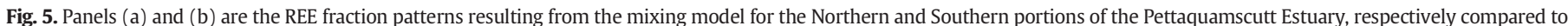

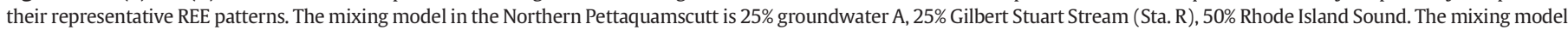

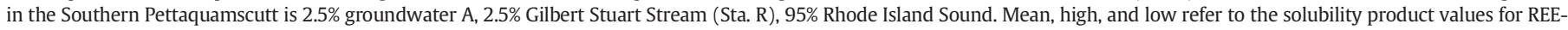

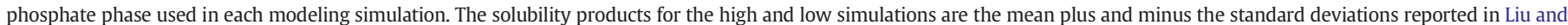

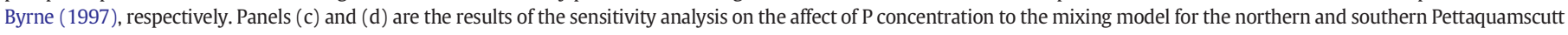
Estuary. 
concentrations and shale-normalized ratios of Station 4 water, but does a reasonable job of reproducing the MREE and HREE concentrations (Fig. 5b).

To evaluate whether the mixing proportions suggested by the REEs are reasonable, we compare the model predicted $\mathrm{Cl}^{-}$concentrations to the measured $\mathrm{Cl}^{-}$for the surface waters. The REE mixing simulation for the southern Pettaquamscutt Estuary produced a $\mathrm{Cl}^{-}$concentration of $441 \mathrm{mmol} \mathrm{kg} \mathrm{m}^{-1}$ that is roughly equivalent to the concentration of Station 4 (453 mmol kg-1; Table 1), which we sought to reproduce with this mixing simulation. For the northern portion of the estuary, the predicted $\mathrm{Cl}^{-}$concentration of $275 \mathrm{mmol} \mathrm{kg}{ }^{-1}$ is somewhat lower than the average concentration of Stations 2 and $3\left(\sim 340 \mathrm{mmol} \mathrm{kg}^{-1}\right.$; Table 1). The difference in $\mathrm{Cl}^{-}$between the model and data for the northern part of the estuary may be due to the use of Connecticut River $\mathrm{Cl}^{-}$data in place of the Gilbert Stuart Stream. Despite the discrepancy between the model output and the actual $\mathrm{Cl}^{-}$data from the northern Pettaquamscutt Estuary, we submit that the model results are reasonable to a first approximation when considering the constraints on available data (i.e., lack of $\mathrm{Cl}^{-}$data for Gilbert Stuart Stream).

The apparent over-prediction of LREE removal by phosphate phases may be due to the use of $\mathrm{P}$ concentrations in the model calculations that are higher than the true values in Rhode Island Sound. The P data reported by Pilson (1985) are from a site in the Narragansett Bay located north of Rhode Island Sound; therefore, the value may not be representative of the P concentrations in the sound. In order to test the sensitivity of the mixing model to $\mathrm{P}$ concentrations, four additional simulations were run using the mean values of the solubility products of REE-phosphate phases from Liu and Byrne (1997) with P concentrations of $0.5 \mathrm{mmol} \mathrm{kg}^{-1}$ and $0.02 \mathrm{mmol} \mathrm{kg}^{-1}$ (detection limit for P analyses; Pilson, 2013) for both portions of the estuary (Fig. $5 \mathrm{c}, \mathrm{d}$ ). The results of these simulations are presented with the shale-normalized REE fractionation patterns from the first simulation described above (i.e., P concentration of $1.23 \mathrm{mmol} \mathrm{kg}^{-1}$ ) and the measured data for the surface waters (Fig. $5 \mathrm{c}$, d). For the northern portion of the Pettaquamscutt Estuary, the mixing model predicts enhanced LREE removal relative to the actual data at all P concentrations (Fig. 5c). In the southern Pettaquamscutt Estuary, the mixing model with a P concentration of $0.5 \mathrm{mmol} \mathrm{kg}{ }^{-1}$ still shows enhanced LREE removal; however, at $[P]=0.02 \mathrm{mmol} \mathrm{kg}^{-1}$, the model predictions for all 14 naturally occurring REEs are substantially improved and closely match the actual measured concentrations (Fig. 5d). The results of the sensitivity analysis presented here suggest that the $\mathrm{P}$ in the Rhode Island Sound endmember must be at the detection limit $\left(0.02 \mu \mathrm{mol} \mathrm{kg}{ }^{-1}\right)$ and that the $P$ in the Gilbert Stuart Stream and groundwater sample A influences the mixing model in the Northern Pettaquamscutt.

The LREE removal in the mixing simulations may indicate that the solubility product data presented by Liu and Byrne (1997) are not appropriate for these calculations. These researchers assumed congruent REE-phosphate dissolution in their experiments, and consequently only measured the $\mathrm{PO}_{4}^{3-}$ concentrations, and not the corresponding REE concentrations, in their REE-phosphate dissolution experiments. Consequently, the substantially lower solubility products for the LREEphosphates compared to MREE- and HREE-phosphates determined by Liu and Byrne (1997) could reflect the assumption of stoichiometric dissolution (e.g., Centiner et al., 2005). For example, the presence of trace amounts of phosphate impurities in the REE phosphate minerals used in the solubility experiments could alter the REE/P ratio in the dissolving fluid, leading to higher $\mathrm{PO}_{4}^{3-}$ than $\mathrm{Ln}^{3+}$ concentrations in the experimental solutions (Centiner et al., 2005). Furthermore, Köhler et al. (2005) noted that during apatite dissolution experiments, secondary phosphate minerals such as rhabdophane precipitated. Because rhabdophane has an affinity for the LREEs, the precipitation of LREE enriched secondary phosphates like rhabdophane during such experiments could affect the solubility constant calculations if stoichiometric dissolution is assumed.
Table 5

The calculated SGD and river fluxes of REEs to the Pettaquamscutt in mmol day ${ }^{-1}$.

\begin{tabular}{llc}
\hline & SGD flux $^{\mathrm{a}}$ & River flux $^{\mathrm{b}}$ \\
\hline $\mathrm{La}$ & $26.2 \pm 11.0$ & 45.3 \\
$\mathrm{Ce}$ & $38.4 \pm 16.2$ & 35.0 \\
$\mathrm{Pr}$ & $5.78 \pm 2.44$ & 9.53 \\
$\mathrm{Nd}$ & $25.6 \pm 10.8$ & 36.7 \\
$\mathrm{Sm}$ & $4.73 \pm 1.99$ & 7.39 \\
$\mathrm{Eu}$ & $0.65 \pm 0.27$ & 1.22 \\
$\mathrm{Gd}$ & $4.51 \pm 1.90$ & 9.14 \\
$\mathrm{~Tb}$ & $0.75 \pm 0.32$ & 1.65 \\
$\mathrm{Dy}$ & $4.72 \pm 1.99$ & 9.46 \\
$\mathrm{Ho}$ & $0.88 \pm 0.37$ & 2.23 \\
$\mathrm{Er}$ & $2.64 \pm 1.12$ & 6.45 \\
$\mathrm{Tm}$ & $0.37 \pm 0.16$ & 1.06 \\
$\mathrm{Yb}$ & $2.33 \pm 0.98$ & 6.48 \\
$\mathrm{Lu}$ & $0.34 \pm 0.15$ & 2.48 \\
\hline
\end{tabular}

a Calculated using an average SGD flux of $6.8 \times 10^{9} \mathrm{~L} \mathrm{yr}^{-1}$

b Flux calculated using a discharge of $1 \times 10^{5} \mathrm{~m}^{3}$ day $^{-1}$ from Siffling(1997).

\subsection{Submarine groundwater discharge of REE to Rhode Island Sound}

The SGD flux of each of the REEs to the Narragansett Bay/Rhode Island Sound was estimated following the same procedures described in Kelly and Moran (2002) for the SGD nutrient fluxes. Specifically, the volumetric flux of SGD $\left(6.8 \times 10^{9} \mathrm{~L} \mathrm{yr}^{-1}\right)$ used in our calculation is an average of the annual groundwater discharge to the Pettaquamscutt Estuary determined using the tidal prism, and the estimated Ra residence time of 8 days and 20 days by Kelly and Moran (2002). The shorter residence time of 8 days reflects a higher groundwater discharge rate necessary to account for the faster Ra removal due to tidal flushing (see Kelly and Moran, 2002, for details). Again, we assumed that the composition of groundwater A is representative of the bulk of the SGD to the Pettaquamscutt Estuary. The resulting estimates of the SGD flux of the REEs are presented in Table 5. The estimated SGD flux of REEs to the Pettaquamscutt Estuary ranges from $0.3 \pm 0.1$ to $38 \pm 16 \mathrm{mmol} \mathrm{day}^{-1}$, with the SGD flux for Nd estimated as $26 \pm 11 \mathrm{mmol} \mathrm{day}^{-1}$ (Table 5). The groundwater flux of Nd is roughly equivalent to the Nd flux from the Gilbert Stuart Stream ( $36.7 \mathrm{mmol} \mathrm{day}^{-1}$ ). The REE fluxes presented in Table 5 can be considered conservative estimates due to the fact that the REE concentrations of groundwater A are much lower than the REE concentrations of the other groundwaters sampled (Table 2). If the bulk SGD to the Pettaquamscutt Estuary has higher REE concentrations than those of groundwater A, then the SGD fluxes of REEs to the estuary would be even greater than the estimates presented in Table 5 .

The results of the SGD REE flux calculations for the Pettaquamscutt Estuary compare well with the SGD REE fluxes calculated for the Indian River Lagoon in Florida, where we computed an SGD flux of $7.69 \pm$ $1.02 \mathrm{mmol} \mathrm{day}^{-1}$ (Chevis et al., in review). The SGD fluxes of Nd at both of these sites are approximately equal to the local $\mathrm{Nd}$ flux of river water Nd fluxes into the estuaries, but the Nd flux to the Pettaquamscutt Estuary is over 3 times greater than that of the Indian River Lagoon. In comparison, the SGD Nd flux estimated by Kim and Kim (2011) for Jeju Island, Korea, is 5 orders of magnitude greater than the SGD Nd flux we estimate for the Pettaquamscutt Estuary (Table 5). The discrepancy is most likely due to the aquifer on Jeju Island being composed of young, easily weathered basaltic rock fragments as opposed to the glacial deposits derived from Late Proterozoic and Paleozoic rocks that characterizes the Pettaquamscutt Estuary watershed. Furthermore, these differences suggest that REE SGD fluxes are highly variable and depend on the structure and composition of the subterranean estuary.

\section{Conclusions}

The rare earth element fractionation patterns for all the Pettaquamscutt groundwater samples in this study have similar 
MREE-enrichments despite a wide range in REE concentrations. The differences in $\mathrm{pH}$ among the Pettaquamscutt groundwaters influence the REE concentrations without causing fractionation among the REE suggesting that solution chemistry does not exert control on the REE fractionation patterns. Removal by colloidal material and reductive dissolution of Fe oxides-oxyhydroxides do not appear to be important processes controlling REE behavior in the Pettaquamscutt. The weathering of REE-bearing minerals such as apatite, accompanied by the precipitation of LREE-enriched secondary phosphate minerals such as rhabdophane, probably exerts more controls on the REE patterns of SGD within the Pettaquamscutt Estuary. The precipitation of the LREEenriched phosphate minerals may be enhanced by the addition of anthropogenic phosphorus by septic tanks and remnants of industrial activities around Narragansett Bay.

Groundwater from the northwestern portion of the estuary appears to have the most influence on the REE patterns due to the higher discharge volume from highly permeable glacial outwash and undifferentiated ice contact deposits located in this portion of the Pettaquamscutt watershed. Even though Pettaquamscutt groundwaters do influence the surface water patterns, the surface water REE patterns have flat to HREE enriched fractionation patterns. The evolution of these surface water patterns is likely due to the continued precipitation of LREE-enriched phosphate minerals.

The estimated SGD flux of Nd to the Pettaquamscutt Estuary using REE concentration from the groundwater in the northwestern portion of the estuary is roughly equivalent to that of the Gilbert Stuart Stream. The similar fluxes from groundwater and river water to the Pettaquamscutt are consistent with the findings in our previous investigation of REEs in the SGD of the Indian River Lagoon in Florida, USA. The fact that the SGD flux is of the same order of magnitude as the Gilbert Stuart Stream points to the need for more REE and Nd isotopic studies in subterranean estuaries in order to establish a global SGD flux of Nd to be employed in determining the oceanic Nd budget.

\section{Acknowledgments}

This work was supported by NSF awards OCE-0825920 to Johannesson and OCE-825895 to Burdige. We thank K.A. Welch, W.B. Lyons, and S.A. Welch at Ohio State University for the major cation and anion analyses. We also thank Remi Marsac and Stephen Lofts for their helpful discussions on REE complexation modeling. This paper was improved by the comments of $\mathrm{O}$. Pourret, an anonymous reviewer, as well as the editor C. Koretsky.

\section{References}

Arsouze, T., Dutay, J.-C., Lacan, F., Jeandel, C., 2009. Reconstructing the Nd oceanic cycle using a coupled dynamical-biogeochemical model. Biogeosci. Discuss. 6, 5549-5588.

Åström, M., Corin, N., 2003. Distribution of rare earth elements in anionic, cationic and particulate fractions in boreal humus-rich streams affected by acid sulphate soils. Water Res. 37, 273-280.

Aubert, D., Stille, P., Probst, A., 2001. REE fractionation during granite weathering and removal by waters and suspended loads: $\mathrm{Sr}$ and Nd isotopic evidence. Geochim. Cosmochim. Acta 65, 387-406.

Banfield, J.E., Eggleton, R.A., 1987. Apatite replacement and rare earth mobilization, fractionation, and fixation during weathering. Clays Clay Miner. 37, 113-127.

Bau, M., 1999. Scavenging of dissolved yttrium and rare earths by precipitation iron oxyhydroxides: experimental evidence for Ce oxidation, Y-Ho fractionation, and lanthanide tetrad effect. Geochim. Cosmochim. Acta 63, 67-77.

Bertram, C.J., Elderfield, H., 1993. The geochemical balance of the rare earth elements and neodymium isotopes in the oceans. Geochim. Cosmochim. Acta 57, 1957-1986.

Bethke, C.M., 2008. Geochemical and Biogeochemical Reaction Modeling. second ed. Cambridge University Press, Cambridge, UK (543 pp.).

Boothroyd, J.C., August, P.V., 2008. Geologic and contemporary landscapes of the Narragansett Bay ecosystem. In: Desbonnet, A., Costa-Pierce, B.A. (Eds.), Science for Ecosystem-based Management: Narragansett Bay in the 21st Century. Springer, New York, pp. 1-33.

Boyle, E.A., Edmond, J.M., Sholkovitz, E.R., 1977. The mechanism of iron removal in estuaries. Geochim. Cosmochim. Acta 41, 1313-1324.

Braun, J.J., Pagel, M., Muller, J.-P., Bilong, P., Michard, A., Guillet, B., 1990. Cerium anomalies in lateritic profiles. Geochim. Cosmochim. Acta 54, 781-795.
Braun, J.J., Viers, J., Dupre, B., Polve, M., Ndam, J., Muller, J.-P., 1998. Solid/liquid REE fractionation in the lateritic system of Goyoum, east Cameroon: the implication for the present dynamics of the soil covers of the humid tropical regions. Geochim. Cosmochim. Acta 62, 273-299.

Buma, G., Frey, F.A., Wones, D.R., 1971. New England granites: trace element evidence regarding their origin and differentiation. Contrib. Mineral. Petrol. 31, 200-320.

Byrne, R.H., Kim, K.-H., 1993. Rare earth precipitation and coprecipitation behavior: The limiting role of $\mathrm{PO}_{4}^{3-}$ on dissolved rare earth concentrations in seawater. Geochim. Cosmochim. Acta 57, 519-526.

Byrne, R.H., Sholkovitz, E.R., 1996. Marine chemistry and geochemistry of the lanthanides. In: Gschneider Jr., K.A., Eyring, L. (Eds.), In Handbook on the Physics and Chemistry of Rare Earths Vol. 23. Elsevier, pp. 497-592.

Burnett, W.C., Bokuniewicz, H., Huettel, M., Moore, W.S., Taniguchi, M., 2003. Groundwater and pore water inputs to the coastal zone. Biogeochemistry 66, 3-33.

Cable, J.E., Burnett, W.C., Chanton, J.P., Weatherly, G.L., 1996. Estimating groundwater discharge into the northeastern Gulf of Mexico using ${ }^{222} \mathrm{Rn}$. Earth Planet. Sci. Lett. 144, 591-604

Centiner, Z.S., Wood, S.A., Gammons, C.H., 2005. The aqueous geochemistry of the rare earth elements. Part XIV. The solubility of rare earth element phosphates from 23 to $150{ }^{\circ} \mathrm{C}$. Chem. Geol. 217, 147-169.

Chaïrat, C., Schott, J., Oelkers, E.H., Lartigue, J.E., Harouiya, N., 2007. Kinetics and mechanism of natural fluorapatite dissolution at $25{ }^{\circ} \mathrm{C}$ and $\mathrm{pH}$ from 3 to 12 . Geochim. Cosmochim. Acta 71, 5901-5912.

Charette, M.A., Sholkovitz, E.R., 2006. Trace element cycling in a subterranean estuary: part 2. Geochemistry of the pore water. Geochim. Cosmochim. Acta 70, 811-826.

Chevis, D.A., Johannesson, K.H., Burdige, D.J., Cable, J.E., Martin, J.B., Roy, M., 2015w. Rare earth element cycling in a sandy subterranean estuary in Florida, USA. Mar. Chem. (in review).

Cline, J.D., 1969. Spectrophotometric determination of hydrogen sulfide in natural waters. Limnol. Oceanogr. 14, 454-458.

De Meneses, J.G.A., 1990. Modeling the Fresh Water Inflow to the Pettaquamscutt River. $\mathrm{Ph}$. D. thesis. University of Rhode Island.

Deer, W.A., Howie, R.A., Zussman, J., 1992. An Introduction to Rock-forming Minerals. 2nd edition. Pearson Education Limited, London.

Delany, J.M., Lundeen, S.R., 1989. The LLNL Thermochemical Database, Lawrence Livermore National Laboratory Report UCRL-21658.

Dia, A., Gruau, G., Olivié-Laquet, G., Riou, C., Molénat, J., Curmi, P., 2000. The distribution of rare earth elements in groundwaters: assessing the role of source- rock composition, redox changes and colloidal particles. Geochim. Cosmochim. Acta 64, 4131-4151.

Dorias, M.J., 2003. The petrogenesis and emplacement of the New Hampshire Plutonic Suite. Am. J. Sci. 303, 447-487.

Dorias, M.J., Wintsch, R.P., Kunk, M.J., Aleinikoff, J., Burton, W., Underdown, C., Kerwin, C.M., 2012. P-T-t conditions, $\mathrm{Nd}$ and $\mathrm{Pb}$ isotopic compositions and detrital zircon geochronology of the Massabesic Gneiss Complex, New Hampshire: isotopic and metamorphic evidence for the identification of Gander basement, central New England. Am. J. Sci. 312, 1049-1097.

Douglas, T.A., Chamberlain, C.P., Blum, J.D., 2002. Land use and geologic controls on the major elemental and isotopic $\left(\delta^{15} \mathrm{~N}\right.$ and $\left.{ }^{87} \mathrm{Sr} /{ }^{86} \mathrm{Sr}\right)$ geochemistry of the Connecticut River watershed, USA. Chem. Geol. 189, 19-34.

Drever, J.I., 1997. The Geochemistry of Natural Waters: Surface and Groundwater Environments. 3rd edition. Prentice Hall, Upper Saddle River, NJ.

Duncan, T., Shaw, T.J., 2003. The mobility of rare earth elements and redox sensitive elements in the groundwater/seawater mixing zone of a shallow coastal aquifer. Aquat. Geochem. 9, 233-255.

Eaton, A.D., Clerceri, L.S., Greenberg, A.E. (Eds.), 1995a. Standard methods for the examination of water and wastewater. Am. Public Health Assoc. 3, pp. 67-68.

Eaton, A.D., Clerceri, L.S., Greenberg, A.E. (Eds.), 1995b. Standard methods for the examination of water and wastewater. Am. Public Health Assoc. 4, pp. 122-123.

Elderfield, H., 1988. The oceanic chemistery of the rare earth elements. Philos. Trans. R. Soc. Lond. A 325, 105-126.

Elderfield, H., Sholkovitz, E.R., 1987. Rare earth elements in the pore waters of reducing nearshore sediments. Earth Planet. Sci. Lett. 82, 280-288.

Elderfield, H. Upstill-Goddard, R. Sholkovitz, E.R. 1990. The rare earth elements in rivers, estuaries, and coastal seas and their significance to the composition of ocean waters. Geochim. Cosmochim. Acta 54, 971-991.

Frank, M., 2002. Radiogenic isotopes: tracers of past circulation and erosional input. Rev. Geophys. 40. http://dx.doi.org/10.1029/2000RG000094.

Gaines, A.G., Pilson, M.E.Q., 1972. Anoxic water in the Pettaquamscutt River. Limnol. Oceanogr. 17, 42-49.

Garrels, R.M., Thompson, M.E., 1962. A chemical model for seawater at $25{ }^{\circ} \mathrm{C}$ and one atmosphere total pressure. Am. J. Sci. 260, 57-66.

German, C.R., Masuzama, T., Greaves, M.J., Elderfield, H., Edmond, J.M., 1995. Dissolved rare earth elements in the Southern Ocean: Cerium oxidation and the influence of hydrography. Geochim. Cosmochim. Acta 59, 1551-1558.

Goldstein, S.L., Hemming, S.R., 2003. Long-lived isotope tracers in oceanography, paleoceanography, and ice-sheet dynamics. Treatise Geochem. 6, 453-489.

Goldstein, S.J., Jacobsen, S.B., 1987. The Nd and Sr isotopic systematics of river-wate dissolved material: implications for the sources of $\mathrm{Nd}$ and $\mathrm{Sr}$ in seawater. Chem. Geol. 66, 245-272.

Goldstein, S.J., Jacobsen, S.B., 1988a. Rare earth elements in river waters. Earth Planet. Sci. Lett. 89, 35-47.

Goldstein, S.J., Jacobsen, S.B., 1988b. REE in the Great Whale River estuary, northwest Quebec. Earth Planet. Sci. Lett. 88, 241-252.

Grandjean, P., Albarède, F., 1989. Ion probe measurements of rare earth elements in biogenic phosphates. Geochim. Cosmochim. Acta 53, 3179-3183. 
Grandjean-Lécuyer, P., Feist, R., Albarède, F., 1993. Rare earth elements in old biogenic apatites. Geochim. Cosmochim. Acta 57, 2507-2514.

Greaves, M.J., Elderfield, H., Klinkhammer, G.P., 1989. Determination of rare earth elements in natural waters by isotope-dilution mass spectrometry. Anal. Chim. Acta. 218, 265-280.

Gromet, L.P., Silver, L.T., 1983. Rare earth element distributions among minerals in a granodiorite and their petrogenetic implications. Geochim. Cosmochim. Acta 48, 2469-2482.

Hannigan, R.E., Sholkovitz, E.R., 2001. The development of middle rare earth element enrichments in freshwaters: weathering of phosphate minerals. Chem. Geol. 175 495-508.

Hanson, G.N., 1980. Rare earth elements in petrogenetic studies of igneous systems. Annu. Rev. Earth Planet. Sci. 8, 371-406.

Haque, S., Ji, J., Johannesson, K.H., 2008. Evaluating mobilization and transport of arsenic in sediments and groundwaters of Aquia aquifer, Maryland, USA. J. Contam. Hydrol. $99,68-84$.

Hermes, O.D., Zartman, R.E., 1985. Late Proterozoic and Devonian plutonic terrains within the Avalon zone of Rhode Island. Geol. Soc. Am. Bull. 96, 272-282.

Hermes, O.D., Gromet, C., Murray, D., 1994. Geologic bedrock map of Rhode Island. Rhode Island Map Series 1. Office of the State Geologist, University of Rhode Island.

Jeandel, C., Bishop, J.K., Zindler, A., 1995. Exchange of neodymium and its isotopes between seawater and small and large particles in the Sargasso Sea. Geochim. Cosmochim. Acta 59, 535-547.

Johannesson, K.H., Burdige, D.J., 2007. Balancing the global oceanic neodymium budget: evaluating the role of groundwater. Earth Planet. Sci. Lett. 253, 129-142.

Johannesson, K.H., Farnman, I.M., Guo, C., Stetzenbach, K.J., 1999. Rare earth element fractionation and concentration variations along a groundwater flow path within a shallow, basin-fill aquifer, southern Nevada, USA. Geochim. Cosmochim. Acta 63, 2697-2708.

Johannesson, K.H., Lyons, W.B., 1994. The rare earth element geochemistry of Mono Lake water and the importance of carbonate complexing. Limnol. Oceanogr. 39, 1141-1154.

Johannesson, K.H., Lyons, W.B., 1995. Rare-earth elements geochemistry of Colour Lake, an acidic freshwater lake on Axel Heiberg Island, Northwest Territories, Canada. Chem. Geol. 119, 209-223.

Johannesson, K.H., Lyons, W.B., Stetzenbach, K.J., Byrne, R.H., 1995. The solubility control of rare earth elements in natural terrestrial waters and the significance of $\mathrm{PO}_{4}^{3-}$ and $\mathrm{CO}_{3}^{2-}$ in limiting dissolved rare earth concentrations: a review of recent information. Aquat. Geochem. 1, 157-173.

Johannesson, K.H., Zhou, X., 1999. Origin of middle rare earth elements in acid waters of a Canadian High Arctic lake. Geochim. Cosmochim. Acta 63, 153-165.

Johannesson, K.H., Lyons, W.B., Yelken, M.A., Gaudette, H.E., Stetzenbach, K.J., 1996 a Geochemistry of the rare earth elements in hypersaline and dilute acidic natural terrestrial waters: complexation, behavior, and middle rare earth element enrichments. Chem. Geol. 133, 125-144.

Johannesson, K.H., Stetzenbach, K.J., Hodge, V.F., Lyons, W.B., 1996b. Rare earth element complexation behavior in circumneutral $\mathrm{pH}$ groundwaters: assessing the role of carbonate and phosphate ions. Earth Planet. Sci. Lett. 139, 305-319.

Johannesson, K.H., Tang, J., Daniels, J.M., Bounds, W.J., Burdige, D.J., 2004. Rare earth element concentrations and speciation in organic-rich blackwaters of the Great Dismal Swamp, Virginia, USA. Chem. Geol. 209, 271-294.

Johannesson, K.J., Cortés, A., Leal, J.A.R., Ramírez, A.G, Durazo, J., 2005. Geochemistry of rare earth elements in groundwaters from a rhyolite aquifer, Central México. In: Johannesson, K.H. (Ed.), In Rare Earth Elements in Groundwater Flow Systems. Elsevier, pp. 187-222.

Johannesson, K.H., Chevis, D.A., Burdige, D.J., Cable, J.E., Martin, J.B., Roy, M., 2011 Submarine groundwater discharge is an important net source of light and middle REEs to coastal waters of the Indian River Lagoon, Florida, USA. Geochim. Cosmochim. Acta $75,825-843$.

Jonasson, R.G., Bancoft, G.M., Nesbit, H.W., 1985. Solubilities of some hydrous REE phosphates with implications for diagenesis and seawater concentrations. Geochim. Cosmochim. Acta 49, 2133-2139.

Kelly, R.P., Moran, S.B., 2002. Seasonal changes in the groundwater input to a well-mixed estuary estimated using radium isotopes and implications for coastal nutrient budgets. Limnol. Oceanogr. 47, 1796-1807.

Kemp, R.A., Truemann, C.N., 2003. Rare earth elements in Solnhofen biogenic apatite: geochemical clues to palaeoenvironment. Sediment. Geol. 155, 109-127.

Kim, I., Kim, G., 2011. Large fluxes of rare earth elements through submarine groundwater discharge (SGD) from a volcanic island, Jeju, Korea. Mar. Chem. 127, 12-19.

Kim, I., Kim, G., 2014. Submarine groundwater discharge as a main source of rare earth elements in coastal waters. Mar. Chem. 160, 11-17.

Klein, C., 2002. The Manual of Mineral Science. 22nd edition. John Wiley and Sons, New York

Klungness, G.D., Byrne, R.H., 2000. Comparative hydrolysis behavior of the rare earth elements and yttrium: the influence of temperature and ionic strength. Polyhedron 19, 99-107.

Köhler, S.J., Harouiya, N., Chaïrat, C., Oelkers, E.H., 2005. Experimental studies of REE fractionation during water-mineral interactions: REE release rates during apatite dissolution from pH 2.8 to 9.2. Chem. Geol. 222, 168-182.

Lawrence, M.G., Kamber, B.S., 2006. The behaviour of rare earth elements during estuarine mixing-revisited. Mar. Chem. 100, 147-161.

Lee, J.H., Byrne, R.H., 1992. Examination of comparative rare earth element complexation behavior using linear free-energy relationships. Geochim. Cosmochim. Acta 56 1127-1137.

Leybourne, M.I., Johannesson, K.H., 2008. Rare earth elements (REE) and yttrium in stream waters, stream sediments, and Fe-Mn oxyhydroxides: fractionation, speciation, and controls over REE + Y patterns in the surface environment. Geochim. Cosmochim. Acta 72, 5962-5983.
Leybourne, M.I., Peter, J.M., Layton-Matthews, D., Volesky, J., Boyle, D.R., 2006. Mobility and fractionation of rare-earth elements during supergene weathering gossan formation and chemical modification of massive sulfide gossan. Geochim. Cosmochim. Acta 70, 1097-1112.

Li, L., Barry, D.A., Stagnitti, F., Parlange, J.Y., 1999. Submarine groundwater discharge and associated chemical inputs to a coastal sea. Water Resour. Res. 35, 3253-3259.

Liu, X., Byrne, R.H., 1997. Rare earth and yttrium phosphate solubilities in aqueous solution. Geochim. Cosmochim. Acta 61, 1625-1633.

Luo, Y.-R., Byrne, R.H., 2001. Yttrium and rare earth element complexation by chloride ions at $25^{\circ} \mathrm{C}$. J. Solut. Chem. 30, 837-845.

Luo, Y.-R., Byrne, R.H., 2004. Carbonate complexation of yttrium and the rare earth elements in natural waters. Geochim. Cosmochim. Acta 68, 691-699.

Luther III, G.W., Kostka, J.E., Church, T.M., Sulzberger, B., Stumm, W., 1992. Seasonal iron cycling in the salt marsh sedimentary environment: the importance of ligand complexes with Fe (II) and Fe (III) in the dissolution of Fe (III) minerals and pyrite, respectively. Mar. Chem. 40, 81-103.

Maria, A., Hermes, O.D., 2001. Volcanic rocks in the Narragansett Basin, southeastern New England: petrology and significance to early basin formation. Am. J. Sci. 301, 286-312.

Marsac, R., Davranche, M., Gruau, G., Dia, A., 2010. Metal loading effect on rare earth on rare earth element binding to humic acid: experimental and modeling evidence. Geochim. Cosmochim. Acta 74, 1749-1761.

Martin, J.B., Cable, J.E., Smith, C., Roy, M., Cherrier, J., 2007. Magnitudes of submarine groundwater discharge from marine and terrestrial sources: Indian River Lagoon, Florida. Water Resour. Res. 43, W05440. http://dx.doi.org/10.10/2007WR005266.

Michael, H.A., Mulligan, A.E., Harvey, C.F., 2005. Seasonal oscillations in water exchange between aquifers and the coastal ocean. Nature 436, 1145-1148.

Middelburg, J.L., Van Der Weijden, C.H., Woittiez, J.R.W., 1988. Chemical processes affecting the mobility of major, minor, and trace elements during weathering of granitic rocks. Chem. Geol. 68, 253-273.

Millero, F.J., 1992. Stability constants for the formation of rare earth inorganic complexes as a function of ionic strength. Geochim. Cosmochim. Acta 56, 3123-3132.

Millero, F.J., Schreiber, D.R., 1982. Use of ion pairing model to estimate the activity coefficients of the ionic components of natural waters. Am. J. Sci. 282, 1508-1540.

Moore, W.S., 1996. Large groundwater inputs to coastal waters revealed by ${ }^{226} \mathrm{Ra}$ enrichments. Nature 380, 612-614.

Moore, W.S., 2010. A reevaluation of submarine groundwater discharge along the southeastern coast of North America. Glob. Biogeochem. Cycles 24, GB4005. http://dx.doi. org/10.1029/2009GB003747.

Moore, W.S., Wilson, A.M., 2005. Advective flow through the upper continental shelf driven by storms, buoyancy, and submarine groundwater discharge. Earth Planet. Sci. Lett. 235, 564-576.

Moore, W.S., Sarmiento, J.L., Key, R.M., 2008. Submarine groundwater discharge revealed by ${ }^{228} \mathrm{Ra}$ distribution in the upper Atlantic Ocean. Nat. Geosci. 1, 309-311.

Muinos, S.B., Frank, M., Maden, C., Hein, J.R., van de Flierdt, T., Lebreiro, S.M., Gaspar, L., Monteiro, J.H., Halliday, A.N., 2008. New constraints on the Pb and Nd isotopic evolution of NE Atlantic water masses. Geochem. Geophys. Geosyst. 9 (2), Q02007. http://dx.doi.org/10.1029/2007GC001766.

Nance, W.B., Taylor, S.R., 1976. Rare earth element patterns and crust evolution - I. Australian post-Archean sedimentary rocks. Geochim. Cosmochim. Acta 40, 1539-1551.

Nixon, S.W. Buckley, B.A Granger, S.L., Harris, LA. Oczkowski, A.J. Fulweiler, R.W., Cole, L.W., 2008. Nitrogen and phosphorus inputs to Narragansett Bay: past, present, and future. In: Desbonnet, A., Costa-Pierce, B.A. (Eds.), Science for Ecosystem-based Management: Narragansett Bay in the 21st Century. Springer, New York, pp. 101-176.

Nowicki, B.L., Gold, A.J., 2008. Groundwater nitrogen transport and input along the Narragansett Bay coastal margin. In: Desbonnet, A., Costa-Pierce, B.A. (Eds.), Science for Ecosystem-based Management: Narragansett Bay in the 21st Century. Springer, New York, pp. 67-100.

Nozaki, Y., Alibo, D.S., 2003. Importance of vertical geochemical processes in controlling the oceanic profiles of dissolved rare earth elements in the northeastern Indian Ocean. Earth Planet. Sci. Lett. 205, 155-172.

Nozaki, Y., Zhang, J., 1995. The rare earth elements and yttrium in the coastal/offshore mixing zone of Tokyo Bay waters and the Kuroshio. In: Sakai, H., Nozaki, Y. (Eds.), Biogeochemical Processes and Ocean Flux in the Western Pacific. Terra Scientific Publishing, pp. 171-184.

Piepgras, D.J., Jacobsen, S.B., 1992. The behavior of rare earth elements in seawater: Precise determination of variations in the North Pacific water column. Geochim. Cosmochim. Acta 56, 1851-1862.

Pilson, M.E.Q., 1985. Annual cycles of nutrients and chlorophyll in Narragansett Bay, Rhode Island. J. Mar. Res. 43, 849-873.

Pilson, M.E.Q., 2013. An Introduction to the Chemistry of the Sea. 2nd edition. Cambridge University Press, New York.

Pitzer, K.S., 1979. Theory: ion interaction approach. In: Pythowicz, R.M. (Ed.), Activity Coefficients in Electrolyte Solutions vol. 1. CRC Press, pp. 157-208.

Plummer, L.N., Parkhurst, D.L., Fleming, G.W., Dunkle, S.A., 1989. PHRQPITZ, a computer program for geochemical calculations in brines. U.S. Geol. Surv. Water-Resour. Invest. Reppp. 88-4153.

Pourret, O., Davranche, M., Gruau, G., Dia, A., 2007. Rare earth element complexation with humic acid. Chem. Geol. 243, 128-141.

Protano, G., Riccobono, F., 2002. High contents of rare earth elements (REEs) in stream waters of a $\mathrm{Cu}-\mathrm{Pb}-\mathrm{Zn}$ mining area. Environ. Pollut. 117, 499-514.

Rosenhein, J.S., Gonthier, J.B., Allen, W.B., 1968. Hydrologic characteristics and sustained yields of principal groundwater units Potowomut-Wickford area, Rhode Island. U. S. Water-Supply Paper 1775. Geological Survey, Washington, DC.

Roy, M., Martin, J.B., Cherrier, J., Cable, J.E., Smith, C.G., 2010. Influence of sea level rise on ron diagenesis in an east Florida subterranean estuary. Geochim. Cosmochim. Acta $74,5560-5573$. 
Roy, M., Martin, J.B., Smith, C.G., Cable, J.E., 2011. Reactive-transport modeling of iron diagenesis and associated organic carbon remineralization in a Florida (USA) subterranean estuary. Earth Planet. Sci. Lett. 304, 191-201.

Schafer, J.P., 1961a. Surficial geology of the Wickford quadrangle, Rhode Island. Quadrangle Map GQ-136. U.S. Geological Survey, Washington, DC

Schafer, J.P., 1961b. Surficial geology of the Narragansett Pier quadrangle, Rhode Island. Quadrangle Map GQ-140. U.S. Geological Survey, Washington, DC.

Schijf, J., Byrne, R.H., 1999. Determination of stability constants for the mono- and diflouro-complexes of Y and the REE, using cation-exchange resin and ICP-MS. Polyhedron 18, 2839-2844.

Schijf, J., Byrne, R.H., 2004. Determination of $\mathrm{SO}_{4} \mathrm{\beta}_{1}$ for yttrium and the rare earth elements at $\mathrm{I}=0.66 \mathrm{~m}$ and $\mathrm{t}=25{ }^{\circ} \mathrm{C}$ - implications for YREE solution speciation in sulfate-rich waters. Geochim. Cosmochim. Acta 68, 2825-2837.

Schulz, K.J., Stewart, D.B., Tucker, R.D., Pollock, J.C., Ayuso, R.A., 2008. The Ellsworth terrane, coastal Maine: geochronology, geochemistry, and $\mathrm{Nd}-\mathrm{Pb}$ isotopic composition implications for the rifting of Ganderia. Geol. Soc. Am. Bull. 120, 1134-1158.

Sholkovitz, E.R., 1976. Flocculation of dissolved organic and inorganic matter during the mixing of river water and sea water. Geochim. Cosmochim. Acta 40, 831-845.

Sholkovitz, E.R., 1978. The flocculation of dissolved Fe, Mn, $\mathrm{Al}, \mathrm{Cu}, \mathrm{Ni}, \mathrm{Co}$ and $\mathrm{Cd}$ during estuarine mixing. Geochim. Cosmochim. Acta 41, 77-86.

Sholkovitz, E.R., 1992. Chemical evolution of rare earth elements: fractionation between colloidal and solution phases of filtered river waters. Earth Planet. Sci. Lett. 114, 77-84.

Sholkovitz, E.R., 1993. The geochemistry of rare earth elements in the Amazon River estuary. Geochim. Cosmochim. Acta 57, 2181-2190.

Sholkovitz, E.R., 1995. The aquatic chemistry of rare earth elements in rivers and estuaries. Aquat. Geochem. 1, 1-34.

Sholkovitz, E.R., Piepgras, D.J., Jacobsen, S.B., 1989. The pore water chemistry of rare earth elements in Buzzards Bay sediments. Geochim. Cosmochim. Acta 53, 2847-2856.

Siffling, J.P., 1997. Narrow River Hydrodynamics Using an ADCP. M.S. thesis. University of Rhode Island.

Sholkovitz, E.R., Landing, W.M., Lewis, B.L., 1994. Ocean particle chemistry: The fractionation of rare earth elements between suspended particles and seawater. Geochim. Cosmochim. Acta 58, 1567-1579.

Smith, C.G., Cable, J.E., Martin, J.B., Roy, M., 2008a. Evaluating the source and seasonality of submarine groundwater discharge using a radon-222 pore water transport model. Earth Planet. Sci. Lett. 273, 312-322.

Smith, C.G., Cable, J.E., Martin, J.B., 2008b. Episodic high intensity mixing events in a subterranean estuary: effects of tropical cyclones. Limnol. Oceanogr. 53, 666-674

Sonke, J.E., Salters, V.J.M., 2006. Lanthanide-humic substances complexation I. Experimental evidence for a lanthanide contraction effect. Geochim. Cosmochim. Acta 70, 1495-1506.

Stolpe, B., Guo, L., Shiller, A.M., 2013. Binding and transport of rare earth elements by organic and iron-rich nanocolloids in Alaska rivers, as revealed by field-flow fractionation and ICP-MS. Geochim. Cosmochim. Acta 106, 446-462.

Sverjensky, D.A., 1984. Europium redox equilibria in aqueous solutions. Earth Planet. Sci. Lett. 67, 70-78.

Tachikawa, K., Athias, V., Jeandel, C., 2003. Neodymium budget in the modern ocean and paleoceanographic implications. J. Geophys. Res. 108, 3254. http://dx.doi.org/10. 1029/1999JC000285.

Tang, J., Johannesson, K.H., 2010. Ligand extraction of rare earth elements from aquifer sediments: implication for rare earth element complexation with organic matter in natural waters. Geochim. Cosmochim. Acta 74, 6690-6705.
Tang, J., Johannesson, K.H., 2006. Controls on the geochemistry of rare earth elements along a groundwater flow path in the Carrizo Sand aquifer, Texas, USA. Chem. Geol. 225, 156-171.

Taniguchi, M., Burnett, W.C., Cable, J.E., Turner, J.V., 2002. Investigation of submarine groundwater discharge. Hydrol. Process. 16, 2115-2129.

Taunton, A.E., Welch, S.A., Banfield, J.F., 2000a. Geomicrobiological controls on light rare earth element, $\mathrm{Y}$ and $\mathrm{Ba}$ distributions during granite weathering and soil formation. J. Alloys Compd. 303-304, 30-36.

Taunton, A.E., Welch, S.A., Banfield, J.F., 2000b. Microbial controls on phosphate and lanthanide distributions during granite weathering and soil formation. Chem. Geol. $169,371-382$

Taylor, S.R., McLennan, S.M., 1985. The Continental Crust: Its Composition and Evolution. Blackwell Scientific Publications, Oxford (UK) (312 pp.).

Tricca, A., Stille, P., Steinmann, M., Kiefel, B., Samuel, J., Eikenberg, J., 1999. Rare earth elements and $\mathrm{Sr}$ and $\mathrm{Nd}$ isotopic compositions of dissolved and suspended loads from small river systems in the Vosges mountains (France), the river Rhine and groundwater. Chem. Geol. 160, 139-158.

Tweed, S.O., Weaver, T.R., Cartwright, I., Schaefer, B., 2006. Behavior of rare earth elements in groundwaters during flow and mixing in fractured rock aquifers: an example from the Dandenong Ranges, southeast Australia. Chem. Geol. 234, 291-307.

Via, R.K., Thomas, D.J., 2006. Evolution of Atlantic thermohaline circulation: early Oligocene onset of deep-water production in the North Atlantic. Geology 34, 441-444.

Welch, S., Lyons, W.B., Kling, C.A., 1990. A coprecipitation technique for determining trace metal concentrations in iron-rich saline solutions. Environ. Sci. Technol. 11, 141-144.

Welch, K.A., Lyons, W.B., Graham, E., Neumann, K., Thomas, J.M., Mikesell, D., 1996. Determination of major element chemistry in terrestrial waters from Antarctica by ion chromatography. J. Chromatogr. A739, 257-263.

Welch, S.A., Taunton, A.E., Banfield, J.F., 2002. Effect of microorganisms and microbial metabolites on apatite dissolution. Geomicrobiol J. 19, 343-367.

Wiesel, C.P., Duce, R.A., Fasching, J.L., 1984. Determination of aluminum, lead, and vanadium in North Atlantic seawater after coprecipitation with ferric hydroxide. Anal. Chem. 56, 1050-1052.

Westerlund, S., Öhman, P., 1992. Rare earth elements in the Arctic Ocean. Deep-Sea Res. 39, 1613-1626.

Willis, S.S., Johannesson, K.H., 2011. Controls on the geochemistry of rare earth elements in sediments and groundwaters of the Aquia aquifer, Maryland, USA. Chem. Geol. 285, 32-49.

Wright, J., Seymour, R.S., Shaw, H.F., 1984. REE and Nd isotopes in conodont apatite: variations with geological age and depositional environment. In: Clark, D.L. (Ed.), Conodont Biofacies and Provincialism. Geol. Soc. Amer. Spec. Pap. 196, pp. 325-340.

Wright, J., Schrader, H., Holser, W., 1987. Paleoredox variations in ancient oceans recorded by rare earth elements in fossil apatite. Geochim. Cosmochim. Acta 51, 631-644.

Zartman, R.E., Hermes, O.D., 1987. Archean inheritance in zircon from late Paleozoic Granites from the Avalon zone of southeastern New England: an African Connection. Earth Planet. Sci. Lett. 82, 305-315.

Zhang, J., Nozaki, Y., 1996. Rare earth elements and yttrium in seawater: ICP-MS determinations in the East Caroline, Coral Sea, and South Fiji basins of the western South Pacific Ocean. Geochim. Cosmochim. Acta 60, 4631-4644. 